\title{
The Rise of Rule Four Institutions: Voluntary Standards, Certification and Labeling Systems
}

\author{
Tracey M. Roberts ${ }^{*}$
}

Voluntary standards, certification and labeling systems are one of many forms of private governance institutions that have been developed in recent years to permit communities to govern without government. These institutions enhance efficiency by internalizing externalized social costs and by meeting consumer preferences associated with risk. This Article advances the existing literature in four ways. First, drawing from Calabresi and Melamed's seminal article, Property Rules, Liability Rules and Inalienability Rules: One View of the Cathedral, the Article explains how these institutions are "Rule 4" institutions - they facilitate the trade of entitlements by lowering steep transaction and information costs. Second, the Article observes that these systems are developed primarily in response to government void and government failure and identifies the rules and structures these systems supply to regulate in the absence of government. The institutions pose interesting implications for the Coase-theorem premise that the main obstacle to internalizing externalities through private sector solutions is the lack of properly defined property rights; these institutions have no authority to define or allocate property rights, and yet they facilitate the exchange of entitlements. Third, the Article identifies the strengths and weaknesses of the systems and suggests ways to support them. Finally, the Article suggests that where governments have adopted voluntary standards, certification and labeling systems to counteract their own allocation of entitlements, an overhaul of existing law to change the original allocation may be in order.

Assistant Professor, University of Louisville, Brandeis School of Law. A.B. Harvard College, J.D. Vanderbilt University Law School, LL.M. New York University School of Law. For helpful comments and suggestions, I thank Tony Arnold, James Chen, Victor Fleischer, Nuno Garoupa, Darian Ibrahim, Laura Rothstein, Joanne Sweeney, Michael Vandenbergh, the 2009-2010 Fellows and the participants of the Searle-Kauffman Institute on Law, Innovation and Growth, the 2011 Association of Law, Property and Society Conference, the 2011 Global Conference on Environmental Taxation, and the 2012 Society for Environmental Law and Economics. The paper was funded in part by a grant from the Meridian Institute. An earlier draft of a portion of this paper will be published as Voluntary Standards, Certification and Labeling Systems: Enhancing Efficiency Through Trade of Entitlements, in MARKET Instruments And Sustainable ECONOMY, Ana Yábar Sterling and Pedro M. Herrera, eds. (Instituto de Estudios Fiscales, Madrid, 2013), ISBN 978-84-8008-356-0. 
I. Voluntary Standards, Certification and Labeling Systems Are Rule Four Institutions

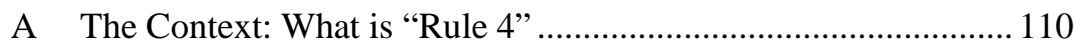

B. Rule 4 Institutions Facilitate the Trade of Entitlements.................116

1. They Reduce Transaction Costs in Global Trade .................... 118

2. They Reduce Assessment Costs Associated with Credence Goods

II. Voluntary Standards, Certification and Labeling Systems Facilitate the Exchange of Entitlements by Substituting for Government at Each Stage of the Regulatory Process

III. Voluntary Standards, Certification and Labeling Systems Arise to Address Government Void and Government Failure

A. Voluntary Standards, Certification and Labeling Systems Address Government Void

B. Voluntary Standards, Certification and Labeling Systems Address Government Failure

IV. Strengths and Weaknesses of Voluntary Standards, Certification and Labeling Systems

A. Strengths: The Systems Overcome Regulatory Capture and Address Regulatory Ossification 139

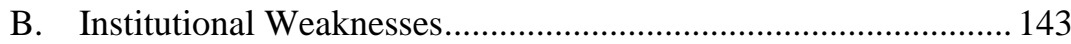

C. Rule 4 Institutions Reveal Inefficient Allocations .......................... 148

Conclusion 153

You never change things by fighting the existing reality. To change something, build a new model that makes the existing model obsolete.

—Richard Buckminster Fuller

\section{INTRODUCTION}

Voluntary standards, certification and labeling systems are private governance institutions - rules and structures that have been developed to govern without the involvement of formal government. These systems are developed when parties who are concerned with the environmental and social impacts of the globalized economy convene and act collectively to develop minimum environmental, labor or other social standards for goods, firms or facilities. They develop a process for verifying whether participants have met the standards, provide training for individuals who will perform the verification 
and use labels to signal to consumers that the standards have been met. ${ }^{1}$ Examples of these systems include the Marine Stewardship Council (MSC) system for labeling sustainably harvested fish, ${ }^{2}$ the Forest Stewardship Council (FSC) system for labeling sustainably harvested forest products, ${ }^{3}$ the Fairtrade Labeling Organization's standards for labor and development, ${ }^{4}{ }^{3}$ the Fair Labor Association standards for labor and human rights conditions, ${ }^{5}$ and the U.S. Green Building Council's Leadership in Energy and Environmental Design (LEED) standards, a cafeteria plan of options for certifying environmentally sustainable buildings, building interiors, schools and neighborhoods based on their location, design, transportation access, materials, energy efficiency and water use. ${ }^{6}$ Organic production standards also began as private governance institutions, setting regional tilth standards that certified and marketed produce grown without synthetic pesticides and herbicides; only later were the standards codified and implemented through state and federal regulatory programs. ${ }^{7}$

Much of the existing scholarship on voluntary standards, certification and labeling systems examines these institutions from the supply side of the economic equation, asking why suppliers submit to certification schemes and what utility they gain from the development and enforcement of these standards. ${ }^{8}$ This Article takes a different approach. It examines these institutions from the demand side, from the perspective of the consumer, and addresses five questions: "What are these institutions?”; "What do they do?”; "Why do they arise?"; "Are they effective?”; and "What are they telling us?"

Part I situates voluntary standards, certification and labeling institutions within the institutional economics and transaction-cost economics literatures. Part II describes the benefits that these systems provide to society, including a description of how they function. Part III examines the contexts in which they arise. This analysis forms the basis of a legal realist critique of the Coase Theorem premise that poorly defined property rights are the central impediment to the trade of entitlements. Part IV examines whether the systems are effective, identifies their strengths and weaknesses, and suggests ways the systems may be improved. This section also notes that the existence of these systems may draw into question the current allocation of entitlements. The last Part offers conclusions.

1. Errol Meidinger, Competitive Supragovernmental Regulation: How Could It Be Democratic? 8 CHI. J. INT’L L. 513, 515 (2008).

2. See MARINE STEWARDSHIP COUNCIL, http://www.msc.org/ (last visited Mar. 5, 2013).

3. See FOREST STEWARDSHIP COUNCIL, http://www.fsc.org/ (last visited Mar. 5, 2013).

4. See FAIRTRADE LABELING ORG., http://www.fairtrade.net/ (last visited Mar. 5, 2013).

5. See FAIR LABOR ASs’N, http://www.fairlabor.org/ (last visited Mar. 5, 2013).

6. See U.S. GREEN BuILDING COUNCIL, http://www.usgbc.org/ (last visited Mar. 5, 2013).

7. See generally SAmuel Fromartz, ORGANIC, InC.: NATURAL FoOdS AND How THEY GREW (2006).

8. See, e.g., Meidinger, supra note 1; Benjamin Cashore et al., Can Non-State Governance 'Ratchet Up' Global Environmental Standards? Lessons from the Forest Sector, 16 REV. EUR. CMTY. \& INT’L ENVTL. L. 158 (2007); Matthew Potoski \& Aseem Prakash, A Club Theory Approach to Voluntary Programs, in Voluntary PROGRAMS 18-39 (2009). 


\section{Voluntary STANDARDS, CERTIFICATION AND LABELING SySTEMS ARE RULE FOUR INSTITUTIONS}

\section{A The Context: What is "Rule 4"}

To understand what voluntary standards, certification and labeling systems are doing in the context of environmental and social externalities, one must first understand the context in which these new institutions have arisen. This understanding requires a brief overview of the history ${ }^{9}$ or evolution ${ }^{10}$ of environmental law and social policy. ${ }^{11}$ While massive industrialization efforts following World War II have given rise to significant global economic growth, they have also led to human dislocation, economic migration and a variety of environmental harms ranging from air and water pollution to toxic waste deposition, overharvesting and waste of natural resources. On the environmental front, ${ }^{12}$ the first regulatory response ${ }^{13}$ in the United States was

9. See Richard Lazarus, The Greening of America and the Graying of United States Environmental Law: Reflections on Environmental Law's First Three Decades in the United States, 20 VA. ENVTL. L.J. 75 (2001).

10. Tony Arnold, Fourth Generation Environmental Law: Integrationist and Multi-Modal, 35 WM. \& MARY ENVTL. L. \& POL’Y REV. 771, 790 (2011).

11. This overview describes the way that environmental law has been developed in the United States. While environmental regulation in other countries has followed alternate routes, it has developed in response to similar social and environmental dilemmas and employs similar regulatory mechanisms to those used in the United States. See, e.g., Monika T. Neumann, The Environmental Law System of the Federal Republic of Germany, 3 ANN. SuRV. INTL. \& COMP. L., 69-71, 77-78 (1996) (describing the modification and amendment of regulations governing economic activities, such as hunting, fishing, water, land use and forest management to incorporate concerns about the ecology and environment in the 1960s and 1970s); see also Christian Hey, EU Environmental Policies: A Short History of the Policy Strategies, in EU ENVIRONMENTAL POLICY HANDBOOK, 18-28 (Stefan Scheuer ed., 2005) (describing the development of Environmental Action Programmes for the European Community following the first United Nations Conference on the Environment in Stockholm in 1972).

12. Similar evolutionary trends have been documented in the labor and employment context. See Orly Lobel, The Renew Deal: The Fall of Regulation and the Rise of Governance in Contemporary Legal Thought, 89 MINN. L. REV. 342, 407-23 (2004) (describing the development of new governance mechanisms in the employment-law and other regulatory contexts, including a shift toward centralized training, job search and social welfare services under the Workforce Investment Act and a shift from command-and-control and litigation-driven enforcement under the Occupational Safety Health Act to collaborative rulemaking and implementation by workers, unions and employers to improve compliance). See generally David M. Trubek \& Louise G. Trubek, New Governance \& Legal Regulation: Complementarity, Rivalry, and Transformation, 13 COLUM. J. EUR. L. 539, 541-42 (2007) (describing the departure of new governance tools from traditional command-and-control forms of governmental regulation to include framework agreements, stakeholder developed rules, revisable standards, experimental programs, benchmarks for improvement, and public and peer participation mechanisms to ensure accountability).

13. Before legislation provided a means to regulate or granted remedies for environmental harms, parties sought to have their concerns addressed through tort litigation. See Lazarus, supra note 9, at 76 ("Yet, prior to 1970, environmental protection law in the United States was essentially nonexistent. Of course, there were a few, isolated states pursuing fledgling efforts, and there were common law property and tort doctrines that some of the more activist judges were willing to invoke on behalf of environmental concerns in private and public lawsuits. But there was nothing even remotely resembling a comprehensive legal regime for regulating pollution of the air, water, or land.”). Tort has a number of shortcomings, however, in addressing environmental harms. Richard Stewart, A New Generation of Environmental Regulation, 29 CAP. U. L. REV. 21, 97 (2001) ("Liability systems generally operate after 
the development of command-and-control regulation. ${ }^{14}$ Firms were required to prevent pollution by cutting production or installing technology that would reduce emissions, and they were barred outright from certain activities that were depleting important natural resources. ${ }^{15}$

The next generation of environmental regulatory forms was developed in response to the inefficiencies and failures of command-and-control regulation. ${ }^{16}$ These newer forms of environmental regulation incorporated flexibility, tapped into market-based economic incentives and weighed the costs as well as the benefits of regulatory action. ${ }^{17}$ Second-generation environmental controls include environmental taxes, behavior-changing subsidies and cap-and-trade programs. The intellectual forebears of these second-generation mechanisms are Arthur Pigou and Ronald Coase.

Arthur Pigou, a British economist, proposed that one way to reduce the social costs associated with negative externalities, such as pollution, would be to impose a tax on the pollution-generating activities. ${ }^{18}$ When the costs of an activity are borne by parties other than those who are benefitting from that activity, the costs are said to have been externalized. If the costs are externalized, the price of the activity to those demanding it will be too low; consequently, public demand for the activity will be higher than optimal. ${ }^{19}$

the fact and generally require a showing that harm or loss was caused by a given actor; these characteristics limit its effectiveness in dealing with some types of environmental harms. For example, damages liability is ill suited for dealing with diffuse risks or harm to health or the environment generated by many sources.”).

14. See Stewart, supra note 13, at 21-25 (describing the history of command-and-control regulation from 1970 to 2000, its shortcomings and the steps of the Administrative Branch to ameliorate them).

15. See Arnold, supra note 10, at 79; Lazarus, supra note 9, at 77-78 (describing the statutory commands of the Clean Air Amendments of 1970, Pub. L. No. 91-604, 84 Stat. 1676 (1970), the Federal Water Pollution Control Act Amendments of 1972, Pub. L. No. 92-500, 86 Stat. 816 (1972), and the Endangered Species Act Amendments of 1973. Pub. L. No. 87 Stat. 884 (1973), to identify and restrict specific categories of destructive activities threatening human health and the environment).

16. See Stewart, supra note 13, at 21 (arguing that command-and-control regulation is "unduly rigid, cumbersome and costly; fails to accommodate and stimulate innovation in resource-efficient means of pollution prevention; fails to prioritize risk management wisely; is patchwork in character, focusing in an uncoordinated fashion on different environmental problems in different environmental media and often ignoring functional and ecosystem interdependencies; and relies on a remote centralized bureaucratic apparatus that lacks adequate democratic accountability”).

17. Arnold, supra note 10, at 791.

18. ARTHUR Pigou, The ECONOMics of Welfare 381 (4th ed. 1932) ("In earlier chapters of this book it has been shown that private enterprise left to itself, even when it operates under conditions of simple competition, often leads to a distribution of resources less favourable to the national dividend than some other possible distributions. In some occupations the value of the marginal private net product of the resources employed is less than the value of the marginal social net product, with the result that too little is invested; in other industries the value of the marginal private net product is the larger, and too much is invested; in yet others the exercise of monopoly power contracts output, and investment falls much below what the public interest requires. When competition rules and social and private net product at the margin diverge, it is theoretically possible to put matters right by the imposition of a tax or the grant of a subsidy; when monopoly rules, it is theoretically possible to render it innocuous by the regulation of price,-in conjunction, in some circumstances, with the regulation of output ....”).

19. The optimal quantity of a good is that at which the social marginal benefits of having the good are equal to the social marginal costs of production. JONATHAN GRUBER, PUBLIC FINANCE AND 
Pigou reasoned that by placing a tax on the pollution equal to the aggregate costs borne by third parties, the price of the good would rise, the demand for the good would be lower, and, in response, the firm would produce fewer goods to meet the reduced demand, imposing lower social costs on the public. ${ }^{20} \mathrm{By}$ imposing an appropriate level tax, the optimal quantity of goods could be reached, since the social benefits the goods generate would offset the social costs associated with their manufacture. ${ }^{21}$

In response to Pigou, Ronald Coase theorized that, under certain conditions, it was unnecessary for government to intervene for society to reach that social optimum. ${ }^{22}$ Coase argued that if property rights were clearly allocated, trade would give rise to an economically efficient allocation of entitlements, so long as there were no costs associated with bargaining. ${ }^{23}$ In other words, if there are no costs associated with finding trading partners, negotiating a price and completing an exchange, parties will exchange entitlements until a Pareto efficient allocation occurs; ${ }^{24}$ trade will continue to occur until no one can be made better off without making another party worse off. ${ }^{25}$ Coase further asserted that an efficient allocation would be reached through trade regardless of how the entitlements were originally allocated. ${ }^{26}$

PUBLIC PoLICY 127 (3d ed. 2010). By taxing each unit of production at a level equal to the marginal damage associated with pollution the government would increase the firm's private marginal cost. Id. at 135. The price of the good would therefore increase and, at the higher price per unit, public demand for the good would be lower. Id. Consequently, the firm would produce fewer goods to meet the lower demand and pollution levels would fall to a level at which the social benefits from having the good would be equal to the social costs of pollution from manufacturing that good. Id. at 124-25 (describing negative production externalities); id. at 135 (describing the use of tax to solve the problem of negative externalities). Production falls in response to lower demand from higher prices that occur when the producer experiences higher private marginal costs of production from imposition of a tax. Id.

20. Id.

21. Id. In the classic example, developed by George Stigler in The Theory of Price, a steel mill is externalizing a portion of the costs of producing steel by emitting pollution into the fishing stream. GeORge Stigler, THE THEORY OF PRICE 105 (1952). The fishermen are bearing the social costs of that pollution in the form of fish kills and catch that may not be fit for consumption. By taxing steel production at a cost equal to the social harm to the fishermen, the price of steel will rise, the demand for steel at that price will be lower, the steel mill will produce less steel to meet the lower demand, and the amount of pollution will drop. The system will reach equilibrium at a level in which the benefits to society of steel are equal to the costs to society of pollution from its production, including the costs to the fishermen concerned with the impact of pollution on their fishing. Id. at 124-25, 130-31, 135.

22. Ronald Coase, The Problem of Social Cost, 3 J. LAW \& ECON. 1 (1960).

23. Id. at 2; GRUBER, supra note 19, at 134.

24. Economists use Pareto efficiency as one standard by which to judge an allocation of resources. If an allocation can make at least one person better off without making anyone worse off (a Pareto improvement), it should be done. If an allocation is not Pareto efficient, economists consider the allocation to be wasteful. HARVEY S. Rosen \& TED GAYER, Public FinANCE 35-38 (2008).

25. In the example involving the steel mill and the fishermen, if the entitlement to be free of pollution were granted to the fishermen, the steel mill would pay the fishermen for the right to pollute.

26. GRUBER, supra note 19 , at 131 . This suggests that an alternate, equally efficient solution in the classic fishermen/steel mill example would be to allocate the right to pollute to the steel mill. If the steel mill were entitled to pollute, the fishermen would aggregate their funds and pay the steel mill what it was worth to them for the steel mill to reduce the discharge of its polluting effluent into the stream. 
Guido Calabresi and Douglas Melamed entered the debate in 1973 with their seminal article, Property Rules, Liability Rules and Inalienability Rules: One View of the Cathedral. ${ }^{27}$ The scholars first took issue with Coase's premise that costless bargaining is a reasonable assumption; ${ }^{28}$ they argued that transaction costs are necessarily present in any trade of entitlements. ${ }^{29}$ Second, they argued that relative transaction costs are precisely what should drive the government's decision about which party should receive the entitlement. ${ }^{30}$ According to Calabresi and Melamed, the first task of the state was to allocate entitlements, to determine which side to favor in the original allocation of rights. ${ }^{31}$ The second task was to determine how best to enforce these rights. ${ }^{32}$ While the bulk of One View of the Cathedral is devoted to answering the second question, delineating when various enforcement rules should be made

27. Guido Calabresi \& A. Douglas Melamed, Property Rules, Liability Rules and Inalienability Rules: One View of the Cathedral, 85 HARV. L. ReV. 1089, 1090-91 (1972). These rules were developed initially by Calabresi in The Cost of Accidents. See Guido Calabresi, THE COSTS OF ACCIDENTS 135-97 (1970).

28. While Coase, himself, recognizes that the assumption of transaction costs is unrealistic, he places this concern to the side, at least initially in The Problem of Social Cost. Coase, supra note 22, at 2 ("I propose to start my analysis by examining a case in which most economists would presumably agree that the problem would be solved in a completely satisfactory manner: when the damaging business has to pay for all damage caused and the pricing system works smoothly (strictly this means that the operation of the pricing system is without cost)."). He later notes that in

order to carry out a market transaction, it is necessary to discover who it is that one wishes to deal with, to inform people that one wishes to deal and on what terms, to conduct negotiations leading up to a bargain, to draw up the contract, to undertake the inspection needed to insure that the terms of the contract are being observed, and so on. These operations are often extremely costly, sufficiently costly at any rate to prevent many transactions that would be carried out in a world in which the pricing system worked without cost.

Id. at 15 . He notes that one possible way to reduce transaction costs might be to organize the transaction within a firm. Id. at 17. This is the solution he had previously explored in Ronald Coase, The Nature of the Firm, 4 ECONOMICA 386 (1937). He also acknowledges that the government may be considered to act as a "superfirm," since it is able to impact the factors of production through administrative rule or decision. Coase, supra note 22, at 17. Coase suggests, however, that government intervention is likely to be inefficient. Id. at 18 ("II]t will no doubt be commonly the case that the gain which would come from regulating the actions which give rise to the harmful effects will be less than the costs involved in Government regulation.”). For this reason, he suggests a further alternative: that one do nothing at all to address the market failure. Id. at 18. ("All solutions have costs and there is no reason to suppose that government regulation is called for simply because the problem is not well handled by the market or the firm."). He concludes that every action has costs and that while aggregate social welfare would be served if the only actions taken were those where what was gained exceeded what was lost, he cautions that in making that evaluation, economists should: 1 ) focus on what may be lost with a reallocation; 2) consider the costs associated with operating mechanisms to allocate entitlements (whether they are in the form of markets or government interventions); and 3) consider the costs of moving to a new system, changing the existing allocation of entitlements. Id. at 44. Each of these considerations would support the de facto existing allocation of entitlements and maintenance of the status quo.

29. Consequently, fewer trades would occur than would be optimal. GRUBER, supra note 19, at 134.

30. Calabresi \& Melamed, supra note 27, at 1090-91; CALABRESI, supra note 27, at 135-97.

31. Id.

32. Calabresi \& Melamed, supra note 27, at 1090-91. 
available, ${ }^{33}$ Calabresi and Melamed outlined a series of five rules for determining how to allocate initial entitlements, given that transaction costs are necessarily present. ${ }^{34}$

First, Rule 1 holds that government should allocate entitlements in a way that best permits parties to perform a cost-benefit analysis by measuring the social benefits of an action (and the costs of obtaining those benefits) against the social costs of the action (and the costs associated with avoiding those social costs). ${ }^{35}$ Under Rule 2, if there is uncertainty about whether the social benefits outweigh the social costs, the government should allocate the costs to the party in the best position to perform the cost-benefit analysis. ${ }^{36}$ Rule 3 further explains Rule 2. It indicates that in the context of harms such as pollution and accidents, the costs should be allocated to those who are in the best position to avoid the accident or prevent the pollution, the so-called "cheapest cost avoider." 37 Rule 4 provides that if there is uncertainty about which party can best ascertain and weigh the benefits and costs of a particular action or activity, the government should place the costs on the party that can, with the lowest transaction costs, use trade to correct an error in entitlements. ${ }^{38}$ In other words, Rule 4 provides that if there is uncertainty about which party is the cheapest cost avoider, the costs should be placed on the party that can most cheaply correct a misallocation of entitlements, ${ }^{39}$ the party Calabresi identifies as the "best briber." ${ }^{40}$ By placing the burden on the party who may most easily

33. Id. at 1092.

34. Id. at 1096 .

35. Id. ("E] $[$ conomic efficiency standing alone would dictate that set of entitlements which favors knowledgeable choices between social benefits and the social costs of obtaining them, and between social costs and the social costs of avoiding them ....”).

36. Id. ("[T]his implies, in the absence of certainty as to whether a benefit is worth its costs to society, that the cost should be put on the party or activity best located to make such a cost-benefit analysis ....”).

37. Id. at 1096-97 ("[I]n particular contexts like accidents or pollution this suggests putting costs on the party or activity which can most cheaply avoid them ....”).

38. Id. at 1097 ("[I]n the absence of certainty as to who that party or activity is, the costs should be put on the party or activity which can with the lowest transaction costs act in the market to correct an error in entitlements by inducing the party who can avoid social costs most cheaply to do so.”). The central goal in placing the costs on the cheapest cost avoider is deterrence- to incentivize that party to take reasonable actions to avoid those costs. CALABRESI, supra note 27 , at 134 . In determining which party is the cheapest cost avoider, one should: 1) avoid spending more on administrative costs in identifying the cheapest cost avoider than one would save in identifying him; 2) allocate the costs among the subcategories of parties based on their statistical likelihood of generating those costs; 3) avoid placing the costs on the party that will likely transfer those costs to a third party that has no ability to prevent those costs; and 4) avoid placing the cost on parties that lack knowledge of the risks and therefore, cannot avoid those costs. Id. at 143-49. Identifying the cheapest cost avoider is made more difficult by assignment and hold-out problems. With assignment problems, there may be many sources of harm and it may be difficult to locate all of them to ensure they bear their fair share. GRUBER, supra note 19 , at $132-33$.

39. See id.

40. CALABRESI, supra note 27, at 150. Considerations in identifying the best briber include evaluating whether parties 1) are aware of the risks, and 2) would be able to identify the party that is the cheapest cost avoider (through repeated market engagements or reduced information costs). Identifying the best briber is further complicated by free-rider problems (situations in which there are multiple 
correct the misallocation, there is greater likelihood that the trades actually occur to move the entitlements toward a Pareto efficient allocation. ${ }^{41}$

Under Rule 5, Calabresi and Melamed posit that the final question that must be answered is whether collective fiat (liability rules) or market transactions (property rules) would facilitate the parties reaching a Pareto optimal result, arguing that whether market transactions actually occur depends largely on the kind of rule used to protect or enforce the entitlement. ${ }^{42}$ The bulk of the remainder of One View of the Cathedral outlines the circumstances when property rules, liability rules or inalienability rules should be used. This Article does not engage with Rule 5 and the vast literature that followed publication of Calabresi and Melamed's article that focuses on the rules for protection and enforcement of rights. ${ }^{43}$ Instead, this Article uses the first four rules as a set of lenses with which to examine the operation of voluntary standards, certification and labeling systems.

When One View of the Cathedral was first published in 1972 there were few examples of the operation of Rule $4 .{ }^{44}$ Twenty-five years later they were still considered to be rare. ${ }^{45}$ Today, however, the operation of Rule 4 appears with greater frequency, facilitated by the appearance of a certain institutional form—voluntary standards, certification and labeling systems. ${ }^{46}$ These systems

bribers and they are each incentivized to underinvest, preferring to free-ride on the payments and efforts of others). GRUBER, supra note 19, at 133-34. It may also be difficult to determine the party that would be best at negotiating trades when the group of cheapest cost avoiders is large. Effective management of the hold-out problem (the decision of one of many cheapest cost avoiders to seek rents from the payor as the price of participation) would likely be a factor in determining which party would be the best briber. Id. at 133.

41. See Calabresi \& Melamed, supra note 27, at 1097.

42. Id. ("[S]ince we are in an area where by hypothesis markets do not work perfectly-there are transaction costs-a decision will often have to be made on whether market transactions or collective fiat is most likely to bring us closer to the Pareto optimal result the 'perfect' market would reach.”).

43. See, e.g., Susan Rose-Ackerman, Inalienability and the Theory of Property Rights, 85 Colum. L. Rev. 91 (1985); James E. Krier \& Stewart Schwab, Property Rules and Liability Rules: The Cathedral in Another Light, 70 N.Y.U. L. REV. 440 (1995); Ian Ayres \& Eric Tally, Solomonic Bargaining: Dividing a Legal Entitlement to Facilitate a Coasian Trade, 104 YALE L.J. 1027 (1995); Louis Kaplow \& Steven Shavell, Property Rules Versus Liability Rules: An Economic Analysis, 109 HARV. L. ReV. 713 (1996); Lee Ann Fennell, Property and Half-Torts, 116 YALE L.J. 1400 (2007); Lee Ann Fennell, Adjusting Alienability, 122 HARV. L. REV. 1402 (2009).

44. Krier \& Schwab, supra note 43, at 444-45 (describing the Spur Industries case, in which the Supreme Court of Arizona required a developer that had constructed a retirement community near a cattle feedlot to pay the feedlot operator reasonable costs associated with shutting down the feedlot and moving it to a new location in order to protect the residents of the retirement community).

45. See id. at 444. ("Logic drove the scholars, but necessity drove the judge-in each instance, and at the same time, to the theretofore nonexistent, and even now rare, rule four.”).

46. These systems are an example of "fourth generation" regulatory mechanisms that are being developed to manage externalities and produce public goods. See generally Arnold, supra note 10, at 773-92 ("Commentators now believe that we are in the third generation of environmental law in the United States, even if there is not total agreement about how to characterize the various generations. U.S. environmental law appears to have evolved from reliance primarily on common-law tort and property doctrines to government reservation and management of lands and natural resources to pollution control and prevention through command-and-control regulation, technology-based standards, and rule-of-law litigation. Some have characterized the latter collection of command-and-control statutes and regulations, administered with technology-based standards and enforced by rule-of-law litigation, as 
make possible the types of trades described by Rule 4 by reducing the steep transaction costs that impede the exchange of entitlements, especially in the context of international commerce.

\section{B. Rule 4 Institutions Facilitate the Trade of Entitlements}

Voluntary standards, certification and labeling systems include, in the price of consumption, the costs associated with averting social and environmental harms. They provide consumers with a means to pay to avoid the social costs that the systems identify. Consumers trade their entitlement to goods otherwise available at lower prices (but with social costs that they or others bear) for higher priced goods that minimize or eliminate those social costs. ${ }^{47}$ Voluntary standards, certification and labeling systems give consumers an opportunity to vote with their wallets by highlighting for consumers the goods with lower social or environmental costs. ${ }^{48}$

the first generation of environmental law. This generational classification is in contrast to what are often referred to as second generation environmental law methods that emphasize regulatory flexibility and the harnessing of economic incentives. These include compliance incentives, negotiated rulemaking (or 'reg. neg.'), and market-based mechanisms. Some believe that the structure and practice of environmental law have now entered a third generational phase with the growing use of collaborative and voluntary processes, outcomes-based instrument choice, and reflexive law principles to achieve sustainable development and engage in ecosystem management. In each case, the new features of environmental law have simply been added to the existing features, making some modifications to the older structure but mostly just adding new generations to the family of environmental law.”). Fourth generation regimes are multimodal. Id. at 794. ("The use of multiple modes or methods in environmental protection can occur in at least three different ways. . . Finally, multimodality might refer to the use of multiple institutions, organizations, groups, or authoritative entities to engage in environmental protection, such as the U.S. Fish and Wildlife Service, the U.S. Forest Service, state wildlife agencies, state natural resource agencies, timber industry groups or the timber industry generally, particular timber companies, local governments, environmental groups, local civic groups, universities and colleges, schools, informal multi-participant groups and networks, groups or networks of scientific experts, federal courts, state courts, and the like.”). Voluntary standards, certification and labeling systems are an independent, private mode of regulation that may complement existing regulatory regimes. Tracey $\mathrm{M}$. Roberts, Innovations in Governance: A Functional Typology of Private Governance Institutions, 22 DUKE ENVT’L. L. \& POL’Y FORUM 132 (2011) (“[P]rivate governance institutions frequently operate as a part of a network or an ensemble regime. Consequently, they may complement one another and, potentially, produce synergistic effects.”). In the face of regulatory failure, they may also attempt to substitute for existing regimes. Id. at 143 ("[T]he institutional sorting process shows that only one type of institution attempts to substitute for government at each stage of the regulatory process: voluntary standards, certification and labeling systems.”). Fourth generation regimes are also integrationist. Arnold, supra note 10, at 796. ("First, at the level of problem framing, environmental law and policy are starting to and will increasingly focus on the interconnectedness within ecological systems, the interconnectedness within social systems, and the interconnectedness between the two types of systems. ... Second, the formulation and implementation of responses to these problems-laws, policies, programs, actions, and so forth-will increasingly require interconnected, coordinated, or collective action by multiple institutions, jurisdictions, agencies, organizations, communities, and individuals in society.”). Voluntary standards, certification and labeling institutions connect stakeholders from civil society, industry and governments, transcending jurisdictional boundaries and sovereignty claims to develop market-based regulatory mechanisms that operate in regional, national and transnational contexts.

47. Consumers are the "best bribers" in the Rule 4 system.

48. See Douglas A. Kysar, Preferences for Processes: The Process/Product Distinction and the Regulation of Consumer Choice, 118 HARV. L. REV. 525, 624-25 (2004); Benjamin Cashore et al., 
For example, consumers concerned about toxic exposures that may lead to cancer, auto-immune disorders, birth defects and hormonal or reproductive disorders may now pay to ensure that the goods they consume are free of toxic materials and substances that cause these problems by purchasing organic produce or "Green Seal"-certified office products and furnishings. ${ }^{49}$ Consumers that are concerned about the global environment, the loss of habitat and extinction of species might buy "Rainforest Alliance"-marked products. ${ }^{50}$ Consumers wanting to avoid purchasing items manufactured or harvested using child labor and slave labor may now pay to ensure that the goods they purchase are manufactured or harvested using fair labor practices under appropriate working conditions. ${ }^{51}$ Coffee buyers concerned that the farmers that pick the beans for the coffee receive an appropriate price may choose "Fairtrade"labeled coffees. ${ }^{52}$

Voluntary standards, certification and labeling systems help consumers overcome several important challenges in exchanging entitlements. First, the public must recognize the social costs that they or others are bearing. The parties that benefit from an activity may not be aware of the harm the activity is causing, and the burdened parties may not be aware of the risks to which they are exposed when harm from an activity is temporally ${ }^{53}$ or geographically distant from the benefit. Second, to trade an entitlement, a prospective seller or purchaser of entitlements must identify the party with whom to trade, ${ }^{54}$ communicate with them, negotiate a price and transfer the entitlement. For most trades, this may require that the parties overcome collective-action

Legitimizing Political Consumerism: The Case of Forest Certification in North America and Europe, in POLITICS, PRODUCTS, AND MARKETS 181 (Michele Micheletti et al. eds., 2003).

49. See Stewart, supra note 13, at 136-37 ("Green Seal is an independent, nonprofit organization focusing on the manufacture and sale of environmentally responsible consumer products. It sets environmental standards and awards a 'Green Seal of Approval' to products that it certifies as having met the standards. Green Seal has certification programs for over thirty products, ranging from shopping bags, water hoses, and heating ducts to tissue paper.”). See also GREEN SEAL, http://www.greenseal.org/ (last visited Mar. 5, 2013).

50. See RAINFOREST ALLIANCE CeRTIFICATION FOR COFFEe, http://www.rainforestalliance.org/agriculture/crops/coffee (last visited Mar. 5, 2013); SUSTAINABLE AGRIC. NETWORK, http://sanstandards.org/sitio/ (last visited Mar. 5, 2013).

51. See FAIR LABOR Ass'N, http://www.fairlabor.org/ (last visited Mar. 5, 2013).

52. See FAIRTRADE LABELING ORG., http://www.fairtrade.net/ (last visited Mar. 5, 2013).

53. For example, the perceivable effects of illness may be discovered well after environmental exposures. To the extent that a pollutant does not have a linear dose-response curve, the threat of illness may escalate suddenly after a period in which the exposure seems to have no impact. See Carol Rose, The Shadow of the Cathedral, 106 YALE L.J. 2175, 2193 (1997) ("[P]ollution harms are more than simply linearly additive. The marginal cost of an additional dose of pollution is very likely to be higher than the marginal cost of the preceding dose."); Arden Rowell, Allocating Pollution, 79 U. CHI. L. REv. 985 (2012) (describing nonlinear dose-response curves for pollution exposures). Significant harm may result from incremental additional exposures because a threshold has been reached or because the threat of harm has a sublinear or supralinear dose-response curve. Id. at 1012-15, 1019-24.

54. The typical environmental problem is not one in which a single polluter impacts many pollution victims, but one in which there are many polluters. Rose, supra note 53, at 2193. In identifying the best briber, some consideration must be given to the ease with which they can identify the party to bribe - the person with whom they can trade. See CALABRESI, supra note 27, at 150-51. 
problems on both sides of the transaction. Specifically, consumers must aggregate demand to justify the transition costs suffered by producers, and producers must aggregate supply to sustain demand over time and reduce the price per unit to a level that would be within reach for the average consumer. Finally, because the "goods" being transferred are credence goods, ${ }^{55}$ purchasers will need assurance that their needs and desires have been met and that the social costs have been avoided. Voluntary standards, certification and labeling systems address each of these impediments to trade.

\section{They Reduce Transaction Costs in Global Trade}

Modern production processes and globalized trade have obscured the social and environmental costs that they generate. As a threshold matter, it may be challenging to identify the environmental or social harms that one or others are bearing. This is an area plagued with uncertainty because the social and environmental costs often attendant to the production of most goods are generally invisible to the consumer in the end product.

A consumer that desires to avoid contributing to overharvesting of natural resources, pollution emitted in manufacturing and distribution chains, or unfair labor and trade practices must undertake extensive research to identify the sources for what she consumes. ${ }^{56}$ To the extent that environmental or social

55. See Michael R. Darby \& Edi Karni, Free Competition and the Optimal Amount of Fraud, 16 J. LAW \& ECON. 67, 68-69 (1973) (“Credence qualities are those which, although worthwhile, cannot be evaluated in normal use. Instead the assessment of their value requires additional costly information.”).

56. In general, a consumer can only be certain that the items she uses are produced according to her preferences either by producing everything she needs by herself or by investigating the sources for all of her consumption. See Andrew King et al., The Strategic Use of Decentralized Institutions: Exploring Certification with ISO 14001 Management Standard, 48 ACAD. MGMT. J. 1091, 1092 (2005) (noting that credence goods impose high search and assessment costs). This would generally require that she engage only in a local economy where she knows the providers personally, can investigate their activities and can develop a trust relationship with those that meet her standards. Some philosophers advocate for this kind of shift in the economy. See Wendell Berry, The Whole Horse, in THE ART OF THE Common-Place: The Agrarian Essays of Wendell Berry 236 (Norman Wirzba ed., 2002). A number of institutions, nongovernmental organizations and networks, have grown out of the Deep Ecology and related philosophical movements, to develop resources to support these choices. Some of these institutions have focused on housing. See Mary M, Lane, In Bioenergy Villages, More Power to the People, WALL ST. J., June 26 2011, http://online.wsj.com/article/SB1000142405274870373080 4576315382880283672.html; Jenny Pickerill, What is Stopping us Building More Eco-houses? PERMACUltuRE (Oct. 31, 2011), http://www.permaculture.co.uk/articles/what-stopping-us-buildingmore-eco-houses; GLOBAL ECOVILLAGE NETWORK, http://gen.ecovillage.org/ (last visited Mar. 5, 2013); Permaculture InST., http://www.permaculture.org/nm/index.php/site/index/ (last visited Mar. 5, 2013). Others have focused on food production and distribution. See Becca Aaronson, Championing the Farm to Table Food Movement, N.Y. TIMES, Sept. 15, 2012, http://www.nytimes.com/ 2012/09/16/us/championing-a-farm-to-table-movement-in-texas.html?_r=0; LOCAL HARVEST, http:// www.localharvest.org/ (last visited Mar. 5, 2013) (supporting community supported agriculture and farmers' markets); SLOW FOOD INT’L, http://www.slowfood.com/ (last visited Mar. 5, 2013) (Developed to "counter the rise of fast food and fast life, the disappearance of local food traditions and people's dwindling interest in the food they eat, where it comes from, how it tastes and how our food choices affect the rest of the world.”). The locavore movement, encouraging the consumption of locally grown foods, has a number of resources for consumers, including LOCAVORE, http://www.getlocavore.com/ (last visited Mar. 5, 2013) (a guide to local food sources), and LOCAVORES, http://www.locavores.com/ 
harms occur in foreign countries, the harms are largely invisible to consumers unless an organization or activist group has brought international notice to the practices. ${ }^{57}$

Foreign production practices may lead to social and environmental harms for a number of reasons. Countries may allocate entitlements differently based on different cultural values or institutional resources. ${ }^{58}$ In states where there are no labor regulations, child labor and slave labor may have been used to manufacture the goods. In states where there are no environmental protection laws, pollution and toxic materials may have significant local, regional and sometimes global environmental impacts. In states where there are no consumer protections, toxic materials that cause cancer, auto-immune disorders, birth defects and hormonal or reproductive disorders may enter global trade. Even where, in principle, jurisdictions regulate, in practice, governments may not enforce their own standards because of a lack of institutional resources or structures. ${ }^{59}$ The challenges of enforcement are compounded by the complexities of the manufacturing process and the difficulty inherent in controlling supply chains that span multiple jurisdictions. ${ }^{60}$ Even consumer goods that are marked with a country-of-origin label have components that may have been manufactured in other countries. ${ }^{61}$ Finding the actual producer of those goods may be more difficult.

(last visited Mar. 5, 2013). A number of diets have been developed to support these kinds of choices including the 100-Mile Diet. See Alisa Smith And J.B. MacKinnon, The 100-Mile Diet: A YeAR OF LOCAL EATING (2007). Some groups have problematized consumption. See JoHn DE GRAAF, DAVID Wann \& Thomas H. Naylor, Affluenza: The All-Consuming Epidemic (2007). Others have developed alternative economic systems, such as local currencies, local exchange trading systems or barter systems for goods and services. See Karen Goldberg Goff, Barter System Reborn, WASH. TIMES (Apr 1, 2009), http://www.washingtontimes.com/news/2009/apr/01/barter-system-reborn/?page=all; Kevin Simpson, Barter System Booms in Colorado, Denver Post (May 21, 2009), http:// www.denverpost.com/ci_12416306. For an example of a local currency system, see BERKSHARES, http://www.berkshares.org/ (last visited Mar. 5, 2013).

57. This appears to be happening more frequently as nongovernmental organizations constitute themselves as investigative and reporting entities organized to disseminate information, increase public awareness of social harms, and sometimes employ "name-and-shame" tactics and consumer boycotts to shift firm behavior or spur legislative action. See Walter Mattli \& Ngaire Woods, In Whose Benefit? Explaining Regulatory Change in Global Politics, in The Politics of Global Regulation 29 (Walter Mattli \& Ngaire Woods eds., 2009) (describing the entrepreneurial role that civic organizations have begun to take in exposing social costs); Sasha Courville, Social Accountability Audits: Challenging or Defending Democratic Governance?, 25 LAW \& POL'Y 269, 271 (2003) (describing civil campaigns to draw attention to the negative societal impacts of the businesses practices of high-profile firms).

58. King et al., supra note 56, at 1093, 1096.

59. David Vogel, The Private Regulation of Global Corporate Conduct, in THE POLITICS OF Global Regulation, supra note 57, at 151, 160. This may result from the lack of institutional resources or the lack of political will.

60. Margaret M. Blair, Cynthia A. Williams \& Li-Wen Lin, The New Role for Assurance Services in Global Commerce, 33 J. CORP. L. 325, 329 (2008); Li-Wen Lin, Legal Transplants Through Private Contracting: Codes of Vendor Conduct in Global Supply Chains, 57 AM. J. CoM. L. 711, 714-16 (2009).

61. Suppliers may enter into subcontracts with firms that do not meet size or other thresholds to outsource risky behaviors and side-step the technical parameters of existing regulations. Michael P. Vandenbergh, The Private Life of Public Law, 105 CoLuM. L. REV. 2029, 2088 (2005). 
Consequently, a consumer seeking to reduce the social or environmental harm arising from her consumption will find it difficult to avoid contributing to these problems without withdrawing entirely from participation in the global economy.

Voluntary standards, certification and labeling institutions overcome these challenges by connecting these consumers with those who harvest, extract and manufacture the goods that they are purchasing. In the words of Calabresi and Melamed, voluntary standards, certification and labeling systems create structures that connect the "best bribers" 62 with the "cheapest cost avoiders." 63 They facilitate communication between these parties and negotiate a trade that meets the consumers' preferences ${ }^{64}$ and the producers' needs.

In addition, voluntary standards, certification and labeling institutions must overcome the communication, coordination and cooperation challenges associated with collective action. These institutions must simultaneously overcome collective-action problems on both sides of the transaction to achieve the economies of scale necessary to sustain the trades. ${ }^{65}$

To achieve a continuous, trusted supply for consumers at a price within reach, they must overcome collective-action problems among producers. The transition from externalizing costs to avoiding them is not cost-free. No single individual could provide sufficient monetary incentives to persuade manufacturers to shift their production practices and shoulder the additional transition costs. ${ }^{66}$ Businesses and manufacturers must foresee sufficient economic benefit to be willing to shift to alternative practices. The prices must be high enough to offset the competitive advantages enjoyed by parties conducting business under the dominant, "business-as-usual" industrial practices. Therefore, voluntary standards, certification and labeling institutions

62. CALABRESI, supra note 27, at 150 . The best bribers are those who can, with the least cost, pay to exchange an existing allocation of entitlements.

63. Calabresi \& Melamed, supra note 27, at 1096-97. The cheapest cost avoiders are the parties that can, with the least cost, change their production practices to minimize or eliminate the social costs to meet the consumers' preferences.

64. Voluntary standards, certification and labeling systems permit consumers to satisfy their preferences by purchasing goods under a certification and labeling scheme. Those concerned about purchasing goods manufactured through child labor, slave labor or unsafe or unsanitary working conditions can purchase goods from companies certified by the Fair Labor Association. See FAIR LABOR Ass'N, http://www.fairlabor.org/ (last visited Mar. 5, 2013). Consumers who would like to minimize their family's exposures to toxic materials may seek out organic food or products marked with the “Green Seal” stamp. See GREEN SEAL, http://www.greenseal.org/ (last visited Mar. 5, 2013).

65. When large numbers of parties are involved on either side of the transaction, communication becomes more difficult. If many parties must be pulled together to trade an entitlement, there are collective action problems; each party individually has the incentive to free ride. If there are a large number of parties from whom entitlements must be purchased, there are coordination problems, including problems with hold-outs. GRUBER, supra note 19, at 133-34.

66. Transition costs include: 1) costs associated with doing business under the new regulatory paradigm; 2) costs associated with transferring assets that are no longer useful under the new paradigm; 3) costs associated with purchasing assets that will be useful under the new paradigm; 4) costs associated with educating workers; and 5) the loss of human capital when employees have specialized to work under the prior conditions. John Quinn \& Michael Trebilcock, Compensation, Transition Costs, and Regulatory Change, 32 U. TORONTO L. J. 117-75 (1982). 
must offer, in the aggregate, a sufficient price premium or other subsidy to incentivize producers to participate and permit them to cover the transition costs associated with changing their methods of production.

To provide a sustained aggregate demand sufficient to cover the producers' transition costs from changing production practices, voluntary standards, certification and labeling systems must overcome collective-action problems among consumers. To aggregate consumer demand, the institutions market their standards to the public to increase awareness of the social costs inherent in the manufacture, harvesting or use of the goods, and to maintain and enhance consumer demand for their products over time. Civic organizations may form norms around their members' purchasing practices to support longterm consumer demand. ${ }^{67}$ Historically, organizations have sometimes also used threats of boycotts, protests and other forms of direct action to expand awareness and enforce those norms. ${ }^{68}$ These activities have both laid the groundwork for the development of voluntary standards, certification and labeling systems, ${ }^{69}$ and they have persuaded retail purchasers to shift to certified goods after the certification and labeling systems were in place. ${ }^{70}$

The price set for certified goods, while covering the transition costs of companies seeking certification as well as the transaction costs of the trade, must also be mutually satisfactory to the parties. Certified goods will need to be produced in sufficient quantities at a price low enough to compete with conventional goods. If the price per unit for the goods is not, sufficient numbers

67. Courville, supra note 57, at 278. See also Graeme Auld, The Emergence of Non-State MarketDriven (NSMD) Global Environmental Governance: A Cross-sectoral Assessment, in GOVERNANCE FOR THE ENVIRONMENT 202-04 (Megali A. Delmas \& Oran Young eds., 2009); CoRA DANKERs, ENVIRONMENTAL AND SOCIAL STANDARDS, CERTIFICATION AND LABELING FOR CASH CROPS 5 (2003).

68. See Tim Bartley, Certifying Forests and Factories: States, Social Movements, and the Rise of Private Regulation in the Apparel and Forest Products Fields, 31 POL. \& SoC’y 433, 443-45 (2003) (describing the history of the development of voluntary standards, certification and labeling systems to address illegal logging and environmentally wasteful and damaging practices in the forestry industry). See also Auld, supra note 67, at 189 ("To increase economic incentives, environmental organizations may act through boycotts and other direct action initiatives to convince large retailers to adopt purchasing policies favoring [non-state market driven] certification schemes.”).

69. For example, in the 1980s, Friends of the Earth, the Rainforest Action Network, Greenpeace and the World Wildlife Fund drew international attention to deforestation occurring in tropical countries. Bartley, supra note 68, at 443. A number of these environmental groups went on to build support for boycotts on tropical timber, focusing on the retailers that imported these products. Id. When timber companies began making claims about the sustainability of their practices, organizations such as the World Wildlife Fund challenged these claims and exposed many of them as spurious. Id. at 444 . In response to false claims of manufacturers, Friends of the Earth developed the Good Wood Seal of Approval, and the Rainforest Alliance and the World Wildlife Fund developed the Forest Stewardship Council to provide assurance to consumers about the source of environmentally preferable sources of timber. Id.

70. For example, Home Depot was the target of a campaign brought by the Rainforest Action Network to expose the company's sale of wood and paper products from old growth forests. They sought to press the company into purchasing sustainably harvested wood sources from Forest Stewardship Council. See Jennifer Krill, Rainforest Action Network, in GoOD COP, BAD Cop: ENVIRONMENTAL NGOS AND THEIR STRATEgIES TOWARD Business 208, 218-19 (Thomas P. Lyon ed., 2010). 
of consumers will not purchase the good. In addition, the supply of the new good must be continuous; if supply lags or falters, consumer interest may dwindle. Therefore, these institutions must assemble sufficient numbers of consumers to sustain demand for certified goods and sufficient numbers of producers to coordinate a sustained shift in production practices.

\section{They Reduce Assessment Costs Associated with Credence Goods}

Voluntary standards, certification and labeling systems must also overcome knowledge problems for consumers. The proposition that markets provide an efficient mechanism for allocating resources rests on the assumption that the parties participating in the exchange have good information about what they are buying. ${ }^{71}$ While market participants seldom achieve perfect information, most are able to ascertain the quality of the goods they purchase through investigation and through trust relationships generated from repeated business. However, consumers have virtually no access to information about what they are purchasing either before purchase, during use or after use for certain kinds of goods known as "credence goods." include legal or medical services, car repair and home maintenance services. With these kinds of products and services, consumers have difficulty overcoming the limits of their knowledge. ${ }^{73}$ In other words, most consumers do not have the expertise to identify and address their legal problem, to diagnose and treat their illness, or to discern what needs to be done to repair their automobiles or home appliances. Even after the legal, medical or repair services have been rendered, consumers often cannot tell whether the services they received solved their problem.

If a buyer cannot discern the quality of the goods before he purchases them, he is not in a position to value the goods and, consequently, cannot pay the proper price for what he is getting. To the extent that consumers can only determine quality at some point in the remote future, they remain unable to rely on their immediate experiences in making subsequent decisions. ${ }^{74}$ Goods may contain harmful components consumers may find it difficult to perceive. While consumers could potentially test whether goods contain harmful substances, the costs of performing those tests would be prohibitively expensive. Unless consumers can reward or sanction the seller through their repeat business and influence on others, the market will not itself discipline errant sellers. This is a market failure.

71. Joseph E. Stiglitz, The Causes and Consequences of the Dependence of Quality on Price, 25 J. ECON. LIT. 1, 13 (1987). Consumers may choose to trade with the vendor that is offering the most satisfactory goods at the best price if they have good information about the quality of the goods they are purchasing and they know the prices at which those goods are being offered by various vendors.

72. Darby \& Karni, supra note 55, at 68-69. See also George A. Akerlof, The Market for "Lemons": Quality Uncertainty and the Market Mechanism, 84 Q.J. ECON. 488 (1970).

73. Darby \& Karni, supra note 55, at 77.

74. Id. at 69. 
These problems are compounded when sellers, having greater knowledge of the goods they are selling, commit fraud by selling goods of a different quality, quantity or type than the buyers think they are purchasing. ${ }^{75}$ Some fraud might be avoided by having one expert evaluate the problem and another expert solve the problem; gathering this information, however, increases transaction costs in terms of both time and expense. ${ }^{76}$ In the absence of any accurate qualitative indicators within consumers' practical reach, buyers sometimes purchase higher-priced goods, thinking that price is a proxy for quality. ${ }^{77}$ They generally lack the capacity to discern whether they are correct, however. ${ }^{78}$

Voluntary standards, certification and labeling systems address credence problems by training and accrediting monitors to certify goods, firms and facilities that meet minimum standards ${ }^{79}$ for one or more consumer

75. Id. at 72 .

76. Id. at 77 .

77. Stiglitz, supra note 71 , at 13 .

78. Id.; Darby \& Karni, supra note 55, at 69 ("Much attention has been focused in public debate upon the credence qualities involved in the provision of repair services . . . . A consumer cannot fully evaluate the repair or a malfunctioning durable good or human being, since he is unfamiliar with the intricacies and peculiarities of the particular machine. Due to lack of knowledge of the inputs of repair services required to maintain given flows of ultimate services from a commodity, the consumer must purchase both information and repair services. If there were no additional costs involved in buying diagnosis and the actual repair service form different sources, then the consumer will generally do so, thereby avoiding the temptation to fraud at no additional cost. If, on the other hand, the cost function is inseparable in the sense that it is cheaper to provide information and service jointly than separately, then the individual tends to buy both information and repair services form the same source.... If ... information is not costless, and output is a stochastic function of input, then the possibility of the existence of fraud has significant scope of interest.”) In the context of most consumer goods for which voluntary standards, certification and labeling systems provide third-party assurance, consumers cannot otherwise determine whether their preferences have been met. This may be true because the qualities they seek (e.g., an ethical or sustainable provenance) do not inhere in the goods and cannot be observed in the end product. $I d$. at 69. Examples of goods with this type of credence quality include goods that are harvested or manufactured using fair labor practices or involving environmentally sustainable extraction or production methods. Even where desirable qualities might inhere in the end product, consumers may also be unable to determine whether their preferences are being met because testing for these desirable qualities would be prohibitively expensive. Id. Examples of this type of credence quality include organic produce, or produce grown in the absence of synthetic pesticides, herbicides and fertilizers.

79. For example, Marine Stewardship Council (sustainable seafood standards), Fairtrade International, Forest Stewardship Council (sustainable forestry standards), Rainforest Alliance/ Sustainable Agriculture Network (conservation of wildlife and wetlands, agricultural worker and community standards), Union for Ethical BioTrade (standards for ethical sourcing of biodiversity products), IOAS (global organic product standards), Responsible Jewellery Council (responsible ethical, human rights, social and environmental standards in the diamond, gold and platinum metals jewellery supply chain), Social Accountability Accreditation Services (labor and working environment standards), 4C Association (sustainable coffee standards) are all full members of the ISEAL Alliance, an organization which sets standards and provides guidance for standards-setting organizations. ISEAL Alliance has developed an Assurance Code that requires member organizations to: 1) identify the minimum qualifications and competency requirements for the personnel who will be performing the auditing services; 2) provide for training of auditing personnel; 3) evaluate auditor competency; and 4) calibrate the auditors to ensure that they are applying the standards consistently. See ISEAL ALLIANCE ASSURANCE CODE, § 6.3 PERSONNEL COMPETENCE (2012), available at http://www.isealalliance.org/ sites/default/files/ISEAL-Assurance-Code-Version-1.0.pdf. 
preferences. Then, they provide assurances to consumers that their preferences have been met through certification and labeling. The labels identify the conforming goods, firms and facilities for the consumer and signal whether, and to what extent, their preferences have been met. ${ }^{80}$ Voluntary standards, certification and labeling systems allow consumers to select against previously hidden unfair trade and labor practices, human rights violations, environmental harm and toxic exposures when they acquire goods and services.

\section{VOLUNTARY STANDARDS, CERTIFICATION AND LABELING SYSTEMS FACILITATE THE EXCHANGE OF ENTITLEMENTS BY SUBSTITUTING FOR GOVERNMENT AT EACH STAGE OF THE REgULATORY PROCESS}

Voluntary standards, certification and labeling systems solve knowledge problems, overcome collective-action problems and lower the transaction costs that would otherwise prohibit the trade of entitlements in a global marketplace. ${ }^{81}$ They regulate by using market structures that substitute for government processes at each the five stages ${ }^{82}$ of the regulatory process: 1 ) agenda-setting; 2) negotiation of standards; 3) implementation; 4) monitoring; and 5) enforcement. ${ }^{83}$

At the "agenda-setting stage" of government regulatory activity, parties bearing externalized harms from a firm activity recognize and publicize the harm, spur media or government institutions to investigate the causes, identify the parties causing the harm, and appeal to government actors to redress the harm and regulate those activities. ${ }^{84}$ Voluntary standards, certification and labeling systems are one of several types of institutions that perform these roles in a private governance context. ${ }^{85}$ First they uncover externalized harms associated with the manufacture and transport of goods and the extraction and harvesting of natural resources. ${ }^{86}$ Voluntary standards, certification and

80. Meidinger, supra note 1 , at 515, 517.

81. These institutions also provide some of their own financial support.

82. Kenneth Abbott and Duncan Snidal identify five stages of the regulatory process, captured by the acronym “ANIME.” Kenneth W. Abbott \& Duncan Snidal, The Governance Triangle: Regulatory Standards Institutions and the Shadow of the Law, in THE POLITICS OF GLOBAL Regulation, supra note 57 , at 46 .

83. The structures that voluntary standards, certification and labeling systems, among other private governance institutions, provide at each stage of the regulatory process are covered in greater detail in Tracey M. Roberts, Innovations in Governance: A Functional Typology of Private Governance Institutions, 22 DUKE ENVT'L. L. \& POL’y FORUM 67 (2011).

84. Abbott \& Snidal, supra note 82, at 63-64.

85. Id. See Roberts, supra note 83, at 78-81, 84-86 (discussing in more detail the structures provided by voluntary standards certification and labeling systems at agenda-setting stage of the regulatory process).

86. For example, the ISEAL Alliance, an institution that provides a code for the development of voluntary standards, certification and labeling systems, requires member organizations to set terms of reference for the standards that identify the need for the standard. See ISEAL ALLIANCE, STANDARDSETTING CODE 5.0, §5.1 TERMS OF REFERENCE (2010) ("Upon commencement of any new standard development activity, the standard-setting organisation shall develop terms of reference (ToRs), which shall include the following elements: A justification of the need for the standard, including an assessment of whether the proposed standard will meet an expressed need; documentation of what other 
labeling systems quantify the magnitude of social costs associated with consumption and clarify the distribution of those social costs. Then, they educate the public about the impacts of their consumption decisions. By exposing the social costs associated with mass production and globalized trade, they set an agenda for consumption and generate public demand for more transparency in manufacturing, resource-extraction and harvesting practices. ${ }^{87}$

At the negotiation and standards-setting stage of the regulatory process, voluntary standards, certification and labeling systems convene stakeholders to determine the appropriate ways to regulate the activity, identify standards for production and develop mechanisms for monitoring and enforcing those standards. They negotiate and set these standards and develop these structures outside of the government context, sidestepping political stalemate, "race-tothe-bottom" dynamics and possibly political capture. ${ }^{88}$ Voluntary standards, certification and labeling systems may also, by recruiting supply-chain anchors, ${ }^{89}$ expand the impact of their standards to other jurisdictions. ${ }^{90}$ When supply-chain anchors require their supply-chain suppliers to meet certain environmental and social standards by contract, the standards are effectively

standards exist or are in the process of development which meet all or part of the expressed need; and an assessment of how broadly the final standard is intended to be applied.").

87. For example, on their website, the Forest Stewardship Council explains why forests are important and why forests are in decline. See Why Forests Matter, FSC FOREST STEWARDSHIP COUNCIL-US, http://us.fsc.org/why-forests-matter.188.htm (last visited Mar. 5, 2013) (“[Forests] filter the water we drink and the air we breathe. Worldwide, 1.6 billion people rely on forests for their livelihoods, including food, clothing, or shelter. Forests are home to nearly half of the world's species, including some of the most endangered birds and mammals, such as orangutans, gorillas, pandas, Northern Spotted Owls and Marbled Murrelets. Deforestation and forest destruction is the second leading cause of carbon pollution, causing 20 percent of total greenhouse gas emissions.... While total acreage of forests in the U.S. remains relatively stable, certain parts of the country are seeing declining forest coverage. For example, the U.S. Forest Service estimates 12 million acres of forest in the Southeast will be lost to suburban real estate development between 1992-2020.”)

88. For example, following a failed attempt to negotiate a forestry treaty at the Earth Summit in 1992, the World Wide Fund for Nature and a number of British firms organized the Forest Stewardship Council to create a private, market-driven regulatory system to slow illegal logging and global deforestation. About Us, FOREST STEWARDSHIP COUNCIL, http://www.fscus.org/about_us (last visited Oct. 7, 2011); Cashore et al., supra note 48, at 182.

89. Supply-chain anchors are the firms that develop the end product or perform retail sales of products; they use contractual provisions to establish minimum requirements for the kinds of products they are willing to purchase.

90. See Michael P. Vandenbergh, The New Wal-Mart Effect: The Role of Private Contracting in Global Governance, 54 U.C.L.A. L. REV. 913 (2007) ("This article focuses on agreements that are entered into in supply chains where pressures on a firm in an importing (often developed) country induce the firm to impose conditions on a firm in an exporting (often developing) country regarding not just the environmental attributes of the good or service purchased, but the environmental attributes of the process by which it was produced. Based on an empirical study of seventy-four firms in eight sectors, the Article finds that over half of those firms impose environmental requirements on their suppliers. The firms that impose these supply-chain requirements are often the largest firms in their sectors, and they represent more than 78 percent of the total sales of the top firms in the sectors studied.”). 
exported to the jurisdictions in which the suppliers operate, regardless of local law. ${ }^{91}$

At the implementation stage, because there is no government mandate for participation, voluntary standards, certification and labeling systems must recruit firms to participate in their regulatory scheme. They do so either by offering "carrots" (incentives) or "sticks" (sanctions).$^{92}$ Incentives appear in the form of favorable press or price premiums. ${ }^{93}$ Voluntary standards, certification and labeling systems may, acting alone ${ }^{94}$ or with other organizations, ${ }^{95}$ pressure supply-chain anchors to participate in the regulatory system. They may also threaten anchor firms with protests, boycotts and negative media campaigns, pressuring firms to shift their production processes. ${ }^{96}$ Firms that participate in the programs avoid negative press associated with the impacts of their activities and receive beneficial media coverage for their efforts to minimize those social costs. ${ }^{97}$ Voluntary standards, certification and labeling systems also devote substantial resources to reduce the transition costs firms face in shifting into new production methods. They create programs to train and accredit consultants who will assist program participants in implementing the certification process ${ }^{98}$ and in auditing the participants after they have sought certification of their goods, firms or facilities. ${ }^{99}$ They also provide technical assistance to new participants to

91. See Margaret M. Blair et al., The New Role for Assurance Services in Global Commerce, 33 J. CORP. L. 325, 337-38 (2008); Li-Wen Lin, Legal Transplants Through Private Contracting: Codes of Vendor Conduct in Global Supply Chains as an Example, 57 AM. J. CoMP. L. 711, 714-16 (2009).

92. Auld, supra note 67, at 189.

93. The institutions are not always able to deliver the price premiums they promise. See Michael Richards, Certification in Complex Socio-political Settings: Looking Forward to the Next Decade, in FOREST TRENDS 26 (2004) (examining certification systems used to govern the harvesting and manufacture of forestry products).

94. See supra note 69.

95. See supra note 70 .

96. Graeme Auld et al., The New Corporate Social Responsibility, 33 AnN. REV. ENV'T \& REsOURCES 413, 424-25 (2008).

97. Id.

98. For example, the U.S. Green Building Council has an accreditation program for professionals who will be guiding projects through the process of obtaining a Leadership in Energy and Environmental Design (LEED) certification. See LEED Professional Credentials, U.S. GREEN BuILDING CounCIL, https://new.usgbc.org/leed/credentials (last visited Mar. 5, 2013). These individuals are designated as "LEED accredited professionals." They are required to pass examinations, and maintain their LEED credentials through work and volunteer experience on LEED projects, additional education, volunteering for the USGBC and its affiliates, and publishing efforts. See Maintain your LEED AP Credential, U.S. GREEN BUILDING COUNCIL, https://new.usgbc.org/leed/credentials/leedap/maintain (last visited Mar. 5, 2013).

99. For example, the Marine Stewardship Council (MSC) and Forest Stewardship Council (FSC) have both contracted with Accreditation Services International (ASI) to accredit auditing firms to perform certification checks. ASI performs field and office audits to verify that the organizations that are certifying firms, goods and services for MSC, FSC and other eco-labels are doing so in compliance with the standards of the label. It verifies that the organizations performing the audits are competent, impartial and capable of doing the audit. If the auditing bodies are not performing audits properly, their accreditation may be suspended. See Articles on Procedures, ASI ACCREDITATION SERVS. INT'L, http://www.accreditation-services.com/archives/category/faq/procedures (last visited Mar. 5, 2013); 
facilitate the use of management systems that will allow participants to monitor their processes internally.

The centerpiece of any voluntary standards, certification and labeling system is the monitoring structure developed to ensure that program participants meet the standards. ${ }^{100}$ This is particularly important for credence goods, since there is little to signal a consumer that the goods they are purchasing are compliant. ${ }^{101}$ Consumers must therefore rely on the reputation of the purveyor or the assurances of other parties to determine whether their preferences have been met. ${ }^{102}$ Voluntary standards, certification and labeling systems train and employ monitors to verify that participants have adhered to the standards and certify the goods, facilities or firms that meet those standards. Frequently, the systems segregate the monitoring functions from the standardssetting functions to avoid conflicts of interest that might otherwise arise. ${ }^{103}$ Monitoring generally occurs on an annual, planned basis and on a random, "spot-check" basis. ${ }^{104}$ Some institutions also provide chain-of-custody mechanisms to ensure that conforming goods are transferred to consumers. ${ }^{105}$ By labeling goods, they signal to consumers that their preferences have been met and that environmental and social harms have been avoided, thereby reducing consumer search costs. ${ }^{106}$

What happens once ASI detects a nonconformity?, ASI ACCREDITATION SERVS. INT'L, http://asi.dfkunde.de/archives/what-happens-once-asi-detects-a-nonconformity (last visited Mar. 5, 2013). Accredited certification bodies carry out annual checks on holders of FSC forest management and chain of custody certificates. See Five Steps Towards FSC Certification, ForEST STEWARDSHIP COUNCIL, http://ic.fsc.org/5-steps-to-certification.36.htm (last visited Mar. 5, 2013).

100. To the extent that the monitoring systems are ineffective, error can not only bring disrepute on the company manufacturing the goods, the supply chain and the retailer, but can undermine the entire certification and labeling system. King et al., supra note 56, at 1094 ("The third-party audits require[d] by certified management standards reduce the risk of decoupling [of the symbolic act of certification from the actual implementation of prescribed practices], but as demonstrated by recent scandals in cost accounting, third-party certification does not guaranty honesty, nor does it prevent changes in practices after certification.... If decoupling becomes too frequent, certification will no longer provide real information for differentiating underlying organizational attributes.”). See, e.g., Declan Walsh \& Steven Greenhouse, Certified Safe, a Factory in Karachi Still Quickly Burned, N.Y. Times, Dec. 7, 2012, http://www.nytimes.com/2012/12/08/world/asia/pakistan-factory-fire-shows-flaws-in-monitoring.html? pagewanted=all\&_r $=0$.

101. King et al., supra note 56, at 1092 (describing consumer monitoring and selection problems). For example, if one chooses organic produce to avoid the risks associated with toxins, one cannot, except through expensive testing discern whether synthetic fertilizers, pesticides, herbicides or other chemicals have been used in the agricultural process. For goods that are certified to verify that labor or trade standards have been met, there is nothing inherent in the good that can be tested to verify that consumer preferences for fair labor and fair trade practices have been met.

102. See Darby \& Karni, supra note 55, at 69 (explaining that consumers often rely on the claims of the service provider in the context of repairs).

103. See Courville, supra note 57, at 283, 287-88.

104. See id. at 288-89.

105. For example, FSC certifies and labels forest products and includes a chain-of-custody tracking process so that consumers may have confidence that they are not purchasing illegally and unsustainably harvested wood. Similarly, MSC, through their certification and labeling of fish and marine products allows consumers to avoid illegal, unreported and unregulated fishing that contributes to the collapse of fisheries throughout the world.

106. See Vogel, supra note 59, at 183. 
Finally, voluntary standards, certification and labeling systems enforce their standards in a number of ways. ${ }^{107}$ On the supply side, they generally reward a firm with positive reputational benefits or price premiums. ${ }^{108}$ If the firms fail to adhere to the certification standards, they may sanction firms with fines and penalties or, if noncompliance continues, they may revoke the certification label. ${ }^{109}$ This would not only deprive the firm of the price premiums associated with the label, but might also expose the firm to unfavorable press, negatively impacting their market position. On the demand side, voluntary standards, certification and labeling institutions facilitate norm development ${ }^{110}$ around consumption decisions. By educating the public about the consequences of their purchasing decisions, they encourage more thoughtful consumption. They clarify and make consumers aware of the social, labor, human rights, environmental and health impacts of their own consumption decisions. They invite consumers to see themselves as citizenconsumers and to use their purchasing power to change social and environmental outcomes. ${ }^{111}$ Ultimately, they permit consumers to pay producers to take actions to reduce or eliminate these externalized social costs.

107. For additional detail on the structures that voluntary standards certification and labeling systems provide at the enforcement stage, see Roberts, supra note 83, at 120-24.

108. Cashore et al., supra note 48, at 181, 186-87.

109. For example, FSC has developed a Policy for Association that delineate the circumstances in which a firm using the FSC label may be dissociated from the organization and be required to discontinue use of the label. See Policy for Association, FOREST STEWARDSHIP COUNCIL INT'L CTR., http://ic.fsc.org/policy-for-association.315.htm (last visited Mar. 5, 2013). The Policy for the Association of Organizations with FSC, FSC-POL-01-004 V2-0 EN, provides that

FSC will only allow its association with organizations that are not directly or indirectly involved in the following unacceptable activities: a) Illegal logging or the trade in illegal wood or forest products, b) Violation of traditional and human rights in forestry operations, c) Destruction of high conservation values in forestry operations, d) Significant conversion of forests to plantations or non-forest use, e) Introduction of genetically modified organisms in forestry operations, f) Violation of any of the ILO Core Conventions defined in the ILO Declaration on Fundamental Principles and Rights at Work.

Id. The FSC Board of Directors, following a due diligence investigation, can make a decision to dissociate and terminate the contractual relationship with an organization or individual that fails to conform to FSC's requirements. Similarly, FLO International, an international standards setting organization for fair trade coffee, uses an independent third party certifier, FLO-Cert GMBH, based in Germany, to perform monitoring and inspections of producers and traders and to enforce the fair trade standards. See Margaret Chon, Marks of Rectitude, 77 FordHAM L. REV. 101, 132-35 (2009). While information about compliance is kept confidential, some participants have been decertified. Id. at 135 (citing Douglas Murray, laura T. Raynolds \& Peter Leigh Taylor, One Cup at a Time: Poverty AlleViation and Fair Trade CoffeE in Latin AMERica 12 (2003)).

110. Individuals who fail to observe norms, or internalized rules, experience mental discomfort and may be shunned within their community. See Michael A. Livermore, Reviving Environmental Protection: Preference Directed Regulation and Regulatory Ossification, 25 VA. ENVTL. L.J. 311, 33233 (2007).

111. Kysar, supra note 48, at 624-25 (2004); Cashore, supra note 48, at 181. 


\section{Voluntary STANDARDS, CERTIFICATION AND LABELING SYSTEMS ARISE TO ADDRESS GOVERNMENT VOID AND GOVERNMENT FAILURE}

Voluntary standards, certification and labeling systems arise primarily in situations marked by "commons" dynamics; that is, they may be subject to the dynamic described by Garrett Hardin as the "tragedy of the commons."112 In Hardin's classic example, pastureland is held in common by a community. Because all members of the community share the costs of supporting the pasture and the benefits from the sale of a herd accrue to the individual herdsmen, each member of that community has the individual incentive to maximize his use of the common resources. ${ }^{113}$ If all members maximize the size of their herds and the time the herds spend on the commonly held pastureland, the pastureland will be depleted more quickly than it can replenish itself, to the detriment of all members of the community. ${ }^{114}$ When all individuals pursue their own interests in using commonly held property without regard to the interests of others or to the future, the frequent outcome is loss of that property's benefit to all members of the community-the so-called "tragedy of the commons." 115 This commons dynamic extends both to situations in which resources are overharvested, such as fisheries and forests, and situations in which the commons are used as sinks or waste dumps, such as use of the atmosphere for depositing ozone-depleting substances or carbon dioxide and other greenhouse gases.

Commons dynamics arise both in contexts in which there is no government to allocate entitlements or enforce property rights and in contexts in which existing governments fail. ${ }^{116}$ Voluntary standards, certification and labeling systems address these challenges by producing rules ${ }^{117}$ and institutions that support a market to trade entitlements. ${ }^{118}$

\section{A. Voluntary Standards, Certification and Labeling Systems Address Government Void}

When there are no government institutions to allocate and enforce property rights, resources that are held in common may be subject to depletion. The combined effects of the tragedy-of-the-commons and race-to-the-bottom dynamics may undercut cooperative efforts to ratify and enforce treaties to

112. See Garrett Hardin, Tragedy of the Commons, 162 SCIENCE 1243 (1968).

113. Id. at 1244.

114. Id.

115. Id.

116. This may occur where regulatory fragmentation undercuts effective regulation, where jurisdictional disjunction bars access to effective remedies, where regulatory capture and uncertainty result in a misallocation of entitlements, and where regulatory remedies ossify and lack the flexibility to respond to changes in human behavior and changes in an environmental system.

117. Edela Schlager, Rationality, Cooperation and Common Pool Resources, 45 AM. BEHAV. SCIENTIST 801, 804 (2002) (recognizing that rules and governing institutions are themselves public goods).

118. Roberts, supra note 83, at 125. 
prevent overharvesting and depletion of resources, such as forests. Voluntary standards, certification and labeling systems address the loss of natural resources due to the tragedy of the commons ${ }^{119}$ by altering incentive structures to create a market for resource protection and sustainable resource harvesting practices.

Common-pool resources, such as fisheries and forests, pose specific kinds of sustainability challenges. Collaboration problems, like those that arise in maintaining common-pool resources, require communities to develop rules relating to harvesting, to develop the means to monitor compliance with those rules and to sanction and deter violations of the rules. ${ }^{120}$ For common-pool resources, the institution must define the boundaries of the resource and create barriers to entry. ${ }^{121}$ To the extent that an institution governing a common-pool resource fails to set boundaries on the resource and limit new entrants, it will not be able to prevent the resource from being depleted. ${ }^{122}$ If a community cannot enforce agreed-upon harvesting limits, either because it cannot ensure that the parties are adhering to the agreement or because it cannot control harvesting by outsiders, it will not be able to maintain the resource for the long term. ${ }^{123}$

Governments may also be subject to institutional dynamics that undercut their ability to effectively regulate. ${ }^{124}$ To attract business investment, employment opportunities for their residents and economic growth, jurisdictions may lower their regulatory requirements and provide incentives to foster a more business- or industry-friendly environment. As jurisdictions compete for business, they may undertake progressively deeper cuts to their regulatory infrastructure, resulting in a race to the bottom. ${ }^{125}$

Voluntary standards, certification and labeling systems seek to overcome, or at least to delay, the loss of common-pool resources through collaboration,

119. See Hardin, supra note 112, at 1243.

120. Oran R. Young, Building Regimes for Socioecological Systems: Institutional Diagnostics, in Institutions and ENVIRONMENTAL Change: PRinciple Findings, ApPlications and Research FrontIERS 115, 123 (Oran R. Young, Heike Schroeder \& Leslie A. King eds., 2008).

121. Id. at 127. See also Elinor Ostrom, GOverning THE COMMONS: THE EVOLUTION of InSTITUTIONS FOR COLLECTIVE ACTION 90 (1990) [hereinafter Ostrom, Governing]; ELINOR OSTROM, UNDERSTANDING INSTITUTIONAL DiverSity 259 (2005) [hereinafter Ostrom, UNDERSTANDING].

122. OSTROM, GOVERNING, supra note 121, at 91-92; OsTROM, UNDERSTANDING, supra note 121, at 260-262. Ostrom identified eight design factors indicative of institutional longevity and robustness seen regularly in private governance institutions developed to govern common pool resources. See OSTROM, GOVERNING, supra note 121, at 90; OSTROM, UNDERSTANDING, supra note 121, at 259. One of the key design factors is that the boundaries for the resource are clearly defined and the governing institution has established clear rules to identify which individuals may use the resource. Ostrom, UNDERSTANDING, supra note 121, at 260-62.

123. Id. This finding comports with Ostrom's observation that, in robust common pool resource regimes, participants often act as their own monitors or choose their own monitors. See Ostrom, GOVERNING, supra note 121, at 265.

124. William W. Buzbee, Recognizing the Regulatory Commons: A Theory of Regulatory Gaps, 89 IOWA L. REV. 1, 26 (2003).

125. See Abbott \& Snidal, supra note 82, at 58. 
cooperation and use of market transactions. The systems address the race-tothe-bottom dynamics by offering market incentives, often in the form of countervailing subsidies, to encourage stakeholders to reduce environmental and social harms. By converting common-pool resources to "club goods,"126 they provide price incentives to club participants (the parties who harvest a resource) to reward them for maintaining resource boundaries and preventing overharvesting. ${ }^{127}$ They engage consumers who are willing to pay a premium for club goods in order to ensure the long-term availability of harvested resources. ${ }^{128}$ The premium paid for club goods covers the additional costs of monitoring the resource, guarding against unauthorized harvesting and enforcing harvesting limits among club participants. ${ }^{129}$

For example, in recent years, technology has permitted the fishing industry to harvest fish in the open seas at rates that have led fisheries to collapse. ${ }^{130}$ While member states of the United Nations developed the "Agreement for the Implementation of the Provisions for the United Nations Convention on the Law of the Sea of 10 December 1982 relating to the Conservation and Management of Straddling Fish Stocks and Highly Migratory Fish Stocks” (Fish Stocks Agreement) to address the overharvesting of fish that straddle exclusive economic zones and high seas boundaries ${ }^{131}$ and to support

126. In general, property may be sorted into four categories based on two characteristics, whether it is subtractive (use by one person diminishes the property or prevents another person from using it) and whether it is excludable (whether other people can be excluded from using it). Private property is both subtractive and excludable; if one person uses private property, others cannot use it and one has the capacity to exclude others from using it based on its physical properties. Common pool resources are goods that are subtractive, but not excludable. As more people use common pool resources, the resources decline in amount or quantity and because of the nature of the resource or its location, people do not have the ability to exclude others from using the resource. "Public goods" are neither subtractive nor excludable. While one cannot bar others from using the resource, their use of that resource does not diminish its availability for others. Finally, "club goods” are not subtractive (they do not diminish from being used by many people) and they are excludable (individuals have the ability to exclude others from their use). When communities create boundaries around common pool resources or otherwise place limits on who may harvest, when they may harvest and the extent they may harvest the resource, they convert those resources to club goods. See generally, Potoski \& Prakash, supra note 8, at 18-39.

127. Id.

128. Id.

129. Id.

130. Jennifer Jacquite \& Daniel Pauly, The Rise of Seafood Awareness Campaigns in an Era of Collapsing Fisheries, 31 MARINE POL'Y 308 (2007). The Food and Agriculture Organization of the United Nations (FAO) has recognized that, of the 200 most important fish stocks, 47 percent are fully exploited, 18 percent are over-exploited, and 10 percent are significantly depleted or recovering from depletion, overfishing and wasteful fishing. See Patricia A. Moye, Private Certification Versus Public Certification in the International Environmental Arena: The Marine Stewardship Council and Marine Eco-Label Japan Fisheries Certification Schemes as Case Studies, 43 VAND. J. TRANSNAT'L L. 533, 536 (2010).

131. The United Nations Convention on the Law of the Sea provides for coastal nations to have exclusive rights to use and explore the ocean and the sea bed extending 200 nautical miles off its coast; these areas are known as the exclusive economic zones. United Nations Convention on the Law of the Sea, pt. 5, art. 55-56, Dec. 10, 1982. The ocean waters beyond the exclusive economic zones are defined as the high seas and are open to navigation, exploration and use by all nation states. Id. pt. 7 , sec. 1 , art. 86-87. 
management of fish stocks in the open seas, the treaty has not been effective. ${ }^{132}$ First, the treaty has no effect on the activities of firms from countries that have not ratified and adopted the treaty. ${ }^{133}$ Unless all countries agree to a treaty and supply the necessary funding and support for enforcement, any firm may relocate to a jurisdiction that is not a party to the treaty and continue unsustainable fishing practices, a process known as "leakage." 134 In addition, as certain species of fish become more scarce, the price associated with those fish rises, further incentivizing new participants to enter the market and existing participants to pursue unsustainable fishing practices. ${ }^{135}$ When all firms do so, however, the rate of harvesting exceeds the rate at which the fish can replenish themselves, resulting in fishery collapse. In addition, even in disputes solely among member-state parties to the Fish Stocks Agreement, issues of sovereignty have complicated enforcement. ${ }^{136}$

This void in government authority creates an opening for private governance institutions. The Marine Stewardship Council (MSC) has attempted to address this void by creating a system to encourage and incentivize sustainable fishing. ${ }^{137}$ They have developed standards for sustainable harvesting, created a certification scheme that verifies whether the standards have been met by the firms that adopt the regime, ${ }^{138}$ provided third-party certification for participating firms ${ }^{139}$ and provided support mechanisms to assist firms in shifting to sustainable harvesting. ${ }^{140}$ They use the MSC label to

132. The Fish Stocks Agreement allocates to regional fisheries management organizations the areas in which they are authorized to perform scientific research to assess and monitor fish stocks, perform surveillance on fishing vessels, and monitor catch limits. The UN Fish Stocks Agreement, art. 9-10, Dec. 11, 2001. Ratifying states are required to enforce the agreement by taking action against vessels that commit serious violations of the agreement and by cooperating with other states to enforce the agreement. Id. art. 18-22.

133. Moye, supra note 130 , at 540.

134. When prices increase as a result of regulation, consumers continue to seek lower priced goods and purchase the goods from jurisdictions where production is not subject to regulations and goods can be sold at a lower price. Michael P. Vandenbergh \& Mark A. Cohen, Climate Change Governance: Boundaries and Leakage, 18 N.Y.U. ENVTL. L.J. 221, 226-29 (2010). This process is known as "leakage." Unless border taxes are imposed on "dirty" goods (goods produced without regulation), "dirty” goods leak into the jurisdiction and out compete "clean” goods on cost. In turn, producers leave the jurisdiction to avoid regulation and reduce their production costs.

135. See James M. Buchanan, Rent-seeking and Profit Seeking, in TOWARD A THEORY OF THE RENT-SEEKING SOCIETY 5 (1980).

136. Moye, supra note 130 , at 540.

137. Id. at 541-42.

138. See MSC Standards and Certification Requirements, MARINE STEWARDSHIP COUNCIL, http://www.msc.org/about-us/standards (last visited Mar. 5, 2013) (describing the requirements and certification process).

139. See Find a Certifier, MARINE STEWARDSHIP COUNCIL, http://www.msc.org/get-certified/finda-certifier (last visited Mar. 5, 2013) (providing information about certifiers and a guide to certification). The certification process is governed at ACCREDITATION SERVS. INT'L, http://www.accreditationservices.com/ (last visited Mar. 5, 2013).

140. Use the MSC Ecolabel, MARINE STEWARDSHIP COUNCIL, http://www.msc.org/get-certified/ use-the-msc-ecolabel (last visited Mar. 5, 2013) (describing the process for obtaining and applying the MSC ecolabel). 
identify sustainably harvested fish and other marine products ${ }^{141}$ and assist participating firms in marketing efforts to gain positive publicity for the supply chains that deliver sustainably harvested fish and the restaurants that serve them to the public. ${ }^{142}$ The organization also educates both the fishing industry and consumers about endangered fish, fishery collapse, ocean ecosystems and the specific actions taken by participating firms to reduce by-catch ${ }^{143}$ and limit harvesting so that the fisheries have an opportunity to replenish themselves. ${ }^{144}$ The labeling system also reminds the public of the consequences of their actions and gives consumers an opportunity to choose an alternative that will ensure that fish will be available for the future-sustainably harvested seafood. ${ }^{145}$

\section{B. Voluntary Standards, Certification and Labeling Systems Address Government Failure}

Voluntary standards, certification and labeling systems also address government failure, situations in which one or more governments have the authority and power to respond, but government is unwilling or unable to act in the best interests of its citizens. ${ }^{146}$ Government failure may occur because of jurisdictional disjunction, jurisdictional overlap, regulatory fragmentation or regulatory capture.

141. Id.

142. See, e.g., Welcome to Your Marketing Toolkit, MARINE STEWARDSHIP COUNCIL, http://marketing.msc.org/en (last visited Mar. 5, 2013).

143. By-catch are fish and other creatures that are caught unintentionally during the process of harvesting marine animals and products. See MSC Environmental Standards for Sustainable Fishing, Principal 3, MARINE STEWARDSHIP COUNCIL, http://www.msc.org/about-us/standards/standards/mscenvironmental-standard (last visited Mar. 5, 2013).

144. See Healthy Oceans, MARINE STEWARDSHIP COUNCIL, http://www.msc.org/healthy-oceans (last visited Mar. 5, 2013) (describing the benefits of certification to fisheries that have adopted MSC fisheries management and certification systems); Track a Fishery, MARINE STEWARDSHIP COUNCIL, http://www.msc.org/track-a-fishery (last visited Mar. 5, 2013) (providing access to an online database that permits the public to track the progress of a fishery through the certification process and identify fisheries that have achieved certification).

145. See Where to Buy, MARINE STEWARDSHIP COUNCIL, http://www.msc.org/where-to-buy (last visited Mar. 5, 2013) (identifying suppliers for businesses and grocery stores, markets and restaurants for consumers that sell MSC certified seafood); Cook, Eat, Enjoy, MARINE STEWARDSHIP COUNCIL, http://www.msc.org/cook-eat-enjoy (last visited Mar. 5, 2013) (identifying fish species that are not under threat and are certified and available for consumption).

146. GRUBER, supra note 19, at 249. The international context often gives rise to government void, because no government has jurisdiction over certain activities that occur in certain areas of the world. For instance, no nation has authority to govern fishing on the high seas and no treaty between nations governs this activity, except to the extent the fishing involves fisheries that straddle the exclusive economic zones and fish stocks that stray into them. In addition, issues of sovereignty prevent realization of treaty goals when nations can come to agreement about how to manage collective resources. In the domestic context, government failure occurs more frequently. Government failure occurs where one or more governments have authority over the persons and resources at stake, but fail to take action. 
Commons dynamics may arise within a jurisdiction and between jurisdictions because of "jurisdictional disjunction."147 Jurisdictional disjunction describes the situation where the geography of the firms, the resources or the harms to be regulated and the jurisdiction of the state or agency that seeks to regulate them may not align. ${ }^{148}$ The government agency petitioned by those harmed may have only incomplete authority over the subject matter or the persons, places or goods involved in the dispute. ${ }^{149}$ The aggrieved parties may not have access to or the right to summon the authority of the governing body that has jurisdiction over the individuals or firms causing the impacts. ${ }^{150}$

Governments may also fail to regulate or to enforce existing regulations because of "jurisdictional overlap." Jurisdictional overlap describes the situation where governments may fail to respond or regulate comprehensively 151 because they would be required to coordinate or collaborate with other governments to achieve an effective resolution of the dilemma. ${ }^{152}$ When many governmental entities are involved, a "regulatory commons" situation may result, or a dynamic in which regulatory authority is so fragmented that no government may be effective. ${ }^{153}$ Governments may fail to regulate in this context because of: 1) status-quo bias and risk aversion; ${ }^{154}$ 2) resistance to sharing information, authority or regulatory control; ${ }^{155}$ and 3) the relative costs of taking action when weighed against the political benefits of doing nothing. ${ }^{156}$

147. See Buzbee, supra note 124, at 24-25. Note that while Professor Buzbee identifies the dynamic as "jurisdictional mismatch," the Author uses the terms "jurisdictional disjunction" and "jurisdictional overlap" instead. This is to avoid confusion and to distinguish the term from Jonathan Adler's more regularly cited use of the phrase "jurisdictional mismatch.” Adler refers to "jurisdictional mismatch as a counterproductive division of authority between federal and state governments over environmental protection duties, resulting in inefficiency, waste, undercutting of innovation and crowding out of effective protection.” See Jonathan H. Adler, Jurisdictional Mismatch in Environmental Federalism, 14 N. Y. U. ENVT’L. L.J. 130 (2005).

148. Id. As an initial matter, regulatory fragmentation makes action difficult for those seeking relief. Buzbee, supra note 124, at 31. If multiple regulators or agencies share jurisdiction over a resource, aggrieved parties may not know where to turn to seek relief and few parties can afford to seek redress in multiple venues. If multiple complainants seek relief from different agencies or governments, no one authority will understand the magnitude of public concern for the problem unless the agencies are communicating with one another. $I d$.

149. Id.

150. Id.

151. Id. at 33. See also Hardin, supra note 112.

152. David Vogel, The Private Regulation of Global Corporate Conduct, in THE POLITICS OF GLOBAL REGULATION, supra note 57, at 151, 159.

153. See Buzbee, supra note 124, 44-54.

154. Id. at 34 .

155. Id. at 50 .

156. Id. at 33. The relative costs of coordinating and collaborating are high when compared to the benefits when the political rewards must be divided among several government actors. Id. at 32-33 (describing the impact of diluted credit claims). When authority is vested among several governmental entities there are greater incentives to free-ride on the efforts of others. Id. at 32 (describing incentives to free-ride). There are also greater incentives to hold-out and vote against regulatory measures. Id. at 3435 ('In democratic systems, it is far easier to block change through use of 'veto gates' and effective 
One common example of regulatory fragmentation is dispersed authority over regional land-use decisions. ${ }^{157}$ Local governments have the authority to govern land-use decisions within their jurisdictional boundaries. Often, though planning on a region-wide basis would be more effective, they fail to coordinate to perform planning that extends outside each of their individual jurisdictional boundaries. Each jurisdiction seeks to expand its tax base; therefore, it competes with its neighbors for development. ${ }^{158}$ Each jurisdiction offers not only subsidies and incentives to attract new business, but also reductions in its regulatory requirements. When each jurisdiction engages in this behavior, the result is a competitive "race to the bottom." 159 When each jurisdiction pursues only its own gain and fails to coordinate and to value resources that it shares in common with neighboring jurisdictions, harm from those decisions spills over to neighboring jurisdictions. The results include urban blight, sprawl, loss of agricultural lands and wildlife habitat, pollution and traffic. ${ }^{160}$

Voluntary standards, certification and labeling systems combat these ills by both cultivating public demand for work and living spaces that avoid these social costs and offering recognition, awards and positive press for developers that build environments that avoid these costs. For example, environmental organizations, designers, land-use planners and the development and construction industry organized the U.S. Green Building Council to address the negative externalities associated with the built environment. ${ }^{161}$ The organization has developed a "cafeteria plan" of standards that incentivize effective land-use planning and efficient building design and construction practices. ${ }^{162}$ The resulting Leadership in Energy and Environmental Design (LEED) standards promote sustainable design and development; the system awards certification points to projects located in urban, in-fill and brownfields environments and denies them to developments that claim agricultural land and wetlands. ${ }^{163}$ The standards also incentivize the development of mixed-use

supermajority requirements than it is to achieve a regulatory change. Stakeholders, be they regulators, demanders or opponents of regulation, also would predictably seek legal 'trumps' to escape unfavorable outcomes.”).

157. Local governments make key land-use decisions, initially seeking growth and increased tax revenues, that in effect result in urban sprawl and its accompanying social harms, a hollowed out business district, congestion in suburban and ex-urban areas, traffic delays, and air pollution. See Buzbee, supra note 124, at 10-11.

158. William W. Buzbee, The Regulatory Fragmentation Continuum, Westway and the Challenges of Regional Growth, 21 J.L. \& PoL. 323, 351 (2005).

159. Buzbee, supra note 124 , at 18.

160. Id.

161. DAVID GOTTFRIED, GREED TO GREEN 167 (2004).

162. See LEED for New Construction, U.S. GREEN BUILDING COUNCIL, http://www.usgbc.org/ DisplayPage.aspx?CMSPageID=220 (last visited Mar. 5, 2013).

163. See LEED New Construction: Site Selection Standards, SSc1, U.S. GREEN BUILDING CounCIL, https://new.usgbc.org/node/1731738?return=/credits/new-construction/v2009 (last visited Mar. 5, 2013). The intent of the site selection criterion is to "avoid the development of inappropriate sites and reduce the environmental impact from the location of a building on a site.” Id. Participants are prohibited from developing "buildings, hardscape, roads or parking areas on portions of sites that meet 
neighborhoods near public transportation. ${ }^{164}$ The system rewards construction practices that reduce the environmental impacts that buildings create from their construction and use. ${ }^{165}$ The organization devotes substantial efforts toward educating building design and construction professionals, government officials, bankers and the general public about the negative impacts of existing land-use and construction practices and the social and environmental benefits of changing to sustainable practices. ${ }^{166}$

Voluntary standards, certification and labeling institutions also arise in situations where governments have allocated entitlements and protect them through enforcement systems, but these allocations fail to serve the interests of all constituents. When there are competing values at stake, governments may allocate entitlements in ways that may be contrary to the desires of much of the public. ${ }^{167}$ In such situations, voluntary standards, certification and labeling systems give the public the opportunity to reallocate entitlements in a way that is different from the government's allocation.

For example, the World Trade Organization (WTO) restricts barriers on trade in order to promote global commerce and economic growth. ${ }^{168}$ While the governing documents and mandates of the WTO include provisions that authorize protection of the environment and labor, ${ }^{169}$ the WTO has, on a

any of the following criteria”: 1) prime farmland; 2) previously undeveloped land within the 100-year floodplain; 3) threatened or endangered species habitat; 4) wetlands areas; 5) areas near wetlands or seas, lakes, rivers, streams and tributaries that support or could support aquatic life, recreational use; and 6) public parkland, unless land of equal or greater value as parkland is accepted in trade by the public landowner. Id.

164. See LEED New Construction: Site Selection Standards, SSc2, U.S. GREEN BUILDING CouncIL, https://new.usgbc.org/node/1731847?return=/credits/new-construction/v2009 (last visited Mar. 5, 2013). The intent of the development density and community connectivity criterion is to "channel development to urban areas with existing infrastructure, protect greenfields and preserve habitat and natural resources." Id. It requires applicants to "construct or renovate a building on a previously developed site AND in a community with a minimum density of 60,000 square feet per acre net" or to construct or renovate a building on a previously developed site, within one-half mile of a residential area or neighborhood with an average density of ten units per acre, and with pedestrian access between the building and ten basic services, such as a bank, place of worship, grocery, day care center, library, medical or dental office. Id.

165. Points are awarded for decisions, designs and buildings that protect or restore habitat, maximize open space, control the quantity and quality of storm water, manage the heat island effect, reduce light pollution and water use, achieve energy performance standards, provide for storage and collection of recyclables, reuse existing buildings and interior elements, manage construction waste, reuse old materials, use recycled, regional, rapidly replaceable and certified sustainable materials, achieve indoor air quality performance standards, use low-emitting materials, and control the source of indoor chemical and air pollutants. See generally LEED New Construction Credits, U.S. GREEN BuILDING CounCIL, https://new.usgbc.org/credits/new-construction/v2009 (last visited Mar. 5, 2013).

166. See About USGBC, U.S. GREEN BUILDING CounCIL, http://www.usgbc.org/Display Page.aspx?CMSPageID=124 (last visited Mar. 5, 2013).

167. Abbott \& Snidal, supra note 82, at 57-58 (suggesting that governing bodies may see regulation impeding economic growth).

168. Id. at 59 .

169. The 1995 Preamble to the Agreement Establishing the World Trade Organization includes recognition of environmental protection and conservation, stating 
number of occasions, held environmental protections to be technical barriers to trade. ${ }^{170}$ The "Technical Barriers to Trade Agreement" prohibits trade discrimination against "like goods." ${ }^{711}$ To the extent that governmental regulations distinguish between products based on characteristics that inhere in the goods, the regulations may be upheld. ${ }^{172}$ Parties to the Technical Barriers to Trade Agreement are barred, however, from making "process distinctions," distinctions between goods based on the processes by which the goods are made. ${ }^{173}$ Distinctions based on whether the goods were extracted, harvested or manufactured under humane or inhumane conditions, using fair labor practices or child and slave labor, or adhering to environmental controls or causing environmental harm, would all be classified as process distinctions. Regulation that distinguishes between goods based on processes may be challenged as nontariff barriers to trade. ${ }^{174}$ If the WTO appellate body finds that a state has erected a barrier to trade and the state refuses to lift the barrier, the challenging state may seek permission from the Dispute Settlement Body to initiate retaliatory trade sanctions. ${ }^{175}$

While the law remains somewhat uncertain because there are a number of exceptions to the doctrine, ${ }^{176}$ and because cases before the WTO lack

The Parties to this Agreement, Recognizing that their relations in the field of trade and economic endeavor should be conducted with a view to raising standards of living, ensuring full employment and a large and steadily growing volume of real income and effective demand, and expanding the production of and trade in goods and services, while allowing for the optimal use of the world's resources in accordance with the objective of sustainable development, seeking both to protect and preserve the environment and to enhance the means for doing so in a manner consistent with their respective needs and concerns at different levels of economic development. ... Agree as follows[.]

Marrakesh Agreement Establishing the World Trade Organization, Apr. 15, 1994, 1867 U.N.T.S. 154.

170. The "Shrimp/Turtle," and "Tuna/Dolphin I" and "Tuna/Dolphin II" cases are illustrative. In the Shrimp/Turtle case, India, Malaysia, Pakistan and Thailand brought claims in the WTO against the United States for erecting a technical barrier to trade by banning importation of shrimp that were harvested in locations and using methods that would kill endangered sea turtles as by-catch. The WTO upheld the U.S. regulation as a process distinction, but determined that the United States had been discriminatory in the implementation of the ban and declared the ban inconsistent with the General Agreement on Tariffs and Trade. Panel Report, United States-Import Prohibition of Certain Shrimp and Shrimp Products, WT/DS58/R (May 15, 1998). In the Tuna/Dolphin I and Tuna/Dolphin II disputes, Mexico brought claims in the WTO against the United States for placing an embargo on tuna products imported from countries that use purse seine fishing methods, which result in a high number of dolphin kills. While the Tuna/Dolphin I case was settled during the negotiation of the North American Free Trade Agreement, the dispute arose again in Tuna/Dolphin II. In May 2012, the appellate tribunal ultimately determined that the dolphin-free tuna label was a technical barrier to trade because the regulation was under-inclusive and did not restrict fishing methods other than purse seine fishing that were also harmful to dolphins. Appellate Body Report, United States-Measures Concerning the Importation, Marketing and Sale of Tuna and Tuna Products, WT/DS381/AB/R (May 16, 2012).

171. Vogel, supra note 59, at 161.

172. Kysar, supra note 48, at 531.

173. Id.

174. See Vogel, supra note 59, at 161.

175. See Understanding the WTO: Settling Disputes, WORLD TRADE ORG., http://www.wto. org/english/thewto_e/whatis_e/tif_e/disp1_e.htm (last visited Mar. 5, 2013).

176. One example of an exception to the doctrine relates to "conflict diamonds." In a number of countries, particularly in West Africa, the diamond trade has been used to finance continual civil war 
precedential value, the product/process distinction has generally prevented governments from imposing process-based regulatory standards. ${ }^{177}$ Private parties are not generally subject to the jurisdiction of the WTO, however, unless they have undertaken activities that may be attributed to one of the WTO nation states. ${ }^{178}$ Consequently, when competing values relating to health, safety and the environment require regulation, and when international trade agreements would otherwise bar action by a nation state or its organs, the public has employed voluntary standards, certification and labeling systems to meet the demand for governance. ${ }^{179}$ By taking their concerns out of the governmental and legislative processes and creating a new institution outside of those contexts, the proponents and developers of these institutions have circumvented entrenched interests and political barriers.

The operation of voluntary standards, certification and labeling systems in the context of government void and government failure has implications for the Coase theorem and its interpreters. In The Problem of Social Cost, Coase suggests that the key impediment to parties managing social costs, or internalizing externalities through trade, is a lack of clarity about which party

and years of gross human rights violations in countries where the diamonds are mined. See generally Lisa Bernstein, Opting Out of the Legal System: Extralegal Contractual Relations in the Diamond Industry, 21 J. LEGAL STUD. 115 (1992). These diamonds are called “conflict diamonds.” A number of nations developed the Kimberley Process, an identification and labeling system, to identify and restrict the trade in conflict diamonds. When those nations requested a WTO waiver from the General Agreement on Tariffs and Trade (GATT) rules to prevent enforcement of the GATT from undermining domestic regulation to implement the Kimberley Process, the WTO granted the waiver. WORLD TRADE Org., Council for Trade in GoOds, Waiver Concerning Kimberley Process Certification SCHEME FOR ROUGH DiAMONDS, G/C/W/432/Rev.1 (03-1136) (2003).

177. Kysar, supra note 48, at 531.

178. See David A. Wirth, The International Organization for Standardization: Private Voluntary Standards as Swords and Shields, 36 B.C. EnvTL. AfF. L. REV. 79, 95 (2009); Rex J. Zedalis, When Do the Activities of Private Parties Trigger WTO Rules? 10 J. INT’L ECON. L 335, 351-53 (2007); Santiago M, Villapando, Attibution of Conduct to the State: How the Rules of State Responsibility May be Applied Within The WTO Dispute Settlement System, 5 J. INT’L ECON. L. 393, 441 (2002).

179. For example, in both the labor and the environmental contexts, attempts at reaching international agreements to advance fair labor practices and safe working conditions and to protect the environment have not only been stymied by the disparate interests of developed and developing nations, but by challenges to proposed state and international laws as nontariff barriers to trade under the GATT. See Bartley, supra note 68, at 447-48. Consequently, governments and organizations seeking to address illegal logging and global depletion of environmental resources have turned to the development of private certification and labeling systems in order to use markets to address these concerns. Id. at 448 (describing the actions of the World Wildlife Federation and the Austrian government to support the development of the Forest Stewardship Council following challenges by Indonesia and Malaysia under the GATT to the Austrian government's proposed ban on tropical timber). In the labor context, governments have collaborated with private firms and labor organizations to develop voluntary standards, certification and labeling systems to monitor factories and certify companies based on fair labor standards after international, treaty-based efforts failed. Specifically, these systems arose when efforts to develop a "global New Deal" and introduce a "social clause" to the GATT failed in the 1994 Uruguay round of trade negotiations and when efforts to include environmental and labor standards in the North American Free Trade Agreement failed. Id. at 448-51, 453-54. 
holds the property rights. ${ }^{180}$ He reasons that the primary role of government in such situations would be to allocate property rights. ${ }^{181}$

Voluntary standards, certification and labeling systems provide an empirical counterexample to this premise. First, these systems operate upon a de facto allocation of property rights. ${ }^{182}$ From a new legal realist perspective, ${ }^{183}$ parties will externalize social costs unless either 1) there is some form of government to prevent their doing so through regulation and enforcement, or 2) the parties facing the social costs have the ability to identify the party harming them and to pay them to stop. Second, these voluntary standards, certification and labeling systems address government void and government failure (the absence of the first option above) by facilitating the second option. They do not clarify property rights; they have no power or authority to do so. Instead, they facilitate the trade of entitlements by addressing the true challenges to managing social costs: knowledge problems, collective-action problems and transaction costs.

\section{STRENGTHS AND WEAKNESSES OF VOLUNTARY STANDARDS, CERTIFICATION AND LABELING SYSTEMS}

\section{A. Strengths: The Systems Overcome Regulatory Capture and Address Regulatory Ossification}

Voluntary standards, certification and labeling systems provide an avenue to bypass regulatory capture. Governments may allocate entitlements in ways that do not benefit the general public because of regulatory capture and corruption. ${ }^{184}$ In contrast to the common claim that regulation overburdens industry, legislation often results in no regulation, weak regulation or regulation

180. Coase, supra note 22, at 8 ("It is necessary to know whether the damaging business is liable or not for damage caused since without the establishment of this initial delimitation of rights, there can be no market transactions to transfer and recombine them.”).

181. He suggests that often, a better solution to government intervention, even where markets and firms cannot address matters efficiently, may be to do nothing - to permit the entitlements to remain where they currently are. $I d$. at 18 . He concludes that "[i]t would be clearly desirable . . in devising and choosing between social arrangements we should have regard for the total effect. This above all is the change in approach which I am advocating." Id.; see also id. at 44 ("A system in which the rights of individuals were unlimited would be one in which there were no rights to acquire.”).

182. In the context of the steel mill and the fishing stream, even without rights to the fishing stream, the steel mill has the de facto right to pollute the fishing stream, and will do so, unless there is either 1) some form of regulation and a means of enforcing it to prevent the steel mill from polluting, or 2) a party willing to "bribe" the mill to reduce its production or otherwise cover the costs associated with preventing the pollution and the ability to enforce that bargain. Voluntary standards, certification and labeling systems suggest that the real impediments to the bargain are knowledge problems and collective-action problems.

183. See Victoria Nourse \& Gregory Shaffer, Varieties of the New Legal Realism: Can a New World Order Prompt a New Legal Theory, 95 CoRnEll L. ReV. 61, 88 (2009) (describing the development of "New Governance" mechanisms to move beyond court-centered, rights-based institutions toward institutional experimentation with collaborative, adaptive problem-solving mechanisms).

184. Mattli \& Woods, supra note 57, at 11; Abbott \& Snidal, supra note 82, at 59. 
that actually provides preferential benefits to certain members of the regulated industry. ${ }^{185}$ There are several reasons why this latter set of outcomes is more common. Pro-regulatory groups, such as environmental organizations and individuals working in the public interest, have higher transaction costs when engaging with the regulatory process because of the difficulty of collective action and the likelihood of free-riding. ${ }^{186}$ In contrast, industry has access to resources and advantages in terms of organization, hierarchy, lines of authority and a profit motivation to lobby successfully against regulation or in favor of lax or preferential regulation. ${ }^{187}$ Consequently, legislation may often be more favorable to regulated industries than to the public, ${ }^{188}$ particularly in states where there are "democracy deficits." 189 Voluntary standards, certification and labeling systems bypass capture by taking the debate outside of the existing government fora, organizing stakeholders to set up private, market-driven mechanisms to encourage the internalization of externalities. ${ }^{190}$

Voluntary standards, certification and labeling systems are also, themselves, resistant to public-choice pathologies and capture from within. Their structures are more directly democratic than the state regulatory apparatus in the United States. Voluntary standards, certification and labeling systems often include structures that provide for transparency and encourage inclusiveness and broad participation by assorted interest groups, enforce procedural due process requirements, and include substantive rules that reflect broader law and social norms. ${ }^{191}$ For example, many of the organizations permit any "interested party" to participate. ${ }^{192}$ Voluntary standards, certification and labeling systems may include these parties as members or stakeholders and they may provide resources to permit low-income individuals and those representing minority interests to participate. ${ }^{193}$

In general, the rulemaking process provides for direct responsiveness to these various constituencies, since rules are developed largely by consensus. ${ }^{194}$ Regulation-setting occurs through a deliberative process that includes a number of familiar procedural due process protections, such as transparency, a public right of comment on proposed rules, the use of reason and reference to the

185. When an industry seeks favorable regulation that will limit competition and allow them to reap greater profits, this practice is known as “rent-seeking.” Buzbee, supra note 124, at 44-45.

186. Id. at 47. See also MAnCur Olson, The Logic of Collective Action, Public Goods And THE THEORY OF GROUPS 142-48 (1965).

187. Buzbee, supra note 124 , at $18,40$.

188. Id. at 44-45.

189. Abbott \& Snidal, supra note 82, at 66-67; Mattli \& Woods, supra note 57, at 15 (noting that a lack of "relative inclusiveness, openness, transparency, fairness, and accessibility of regulatory institutions," or deficiencies in the democratic process or of democratic institutions, will correlate with regulatory capture).

190. See Auld, supra note 67.

191. Meidinger, supra note 1 , at 533.

192. Id. at 526 .

193. Id. at 526-27. Industry-based organizations, however, tend to strictly limit participation to select industry groups and firms when setting the organization's regulations.

194. Id. 
results of empirical investigations in deliberation, consensus-based decisionmaking, monitoring and evaluation of policy impacts, and structures to later modify policies to improve performance based on these evaluations. ${ }^{195}$ The regulations are often based in familiar sources of law, including international treaties, United Nations documents, state laws, and the rules and regulations of academic and professional associations. ${ }^{196}$ Voluntary standards, certification and labeling systems show deference for, and sometimes incorporate by reference, the public laws of the country in which they are to be applied. ${ }^{197}$

The competition between multiple voluntary standards, certification and labeling systems designed to regulate the same set of goods may partially explain the resistance to regulatory capture. ${ }^{198}$ They face competition with other governance systems for acceptance and legitimacy; this competition "fosters more democratic responsiveness than is traditionally the case with state regulatory agencies." ${ }^{199}$ Voluntary standards, certification and labeling systems appear to respond to the competitive dynamic to choose the rules that will generate broad acceptance. ${ }^{200}$ In short, they embody a "democratic experimentalism.”201

Because voluntary standards, certification and labeling systems are voluntary, they do not impose the sharp transition costs that government regulation may generate. ${ }^{202}$ They therefore generate less resistance from industry and avoid much of the deadweight loss associated with lobbying ${ }^{203}$ while educating the public about the social costs of business as usual and

195. Id. at 529 .

196. Id.

197. Id. at 530.

198. Id. at 531.

199. Id.

200. Id. at 533.

201. Id. at 526.

202. When government imposes minimum compliance standards, firms experience transition costs in retrofitting their equipment and operations to meet the standards. These transition costs are often passed on to consumers. Firms can choose to pay to retrofit their facilities to meet the standards or reduce production to reduce their pollution output. To the extent that firms cannot adhere to the minimum compliance standards, either through abatement or reducing production, in a cost-effective manner, they will be forced out of the business of supplying the good. This scenario results in an initial reduction in supply. While supply is reduced, demand initially remains the same, increasing prices. Consumers will be forced to pay the higher prices for the goods, to find substitute goods, or to do without the good. In addition, firms receive a windfall to the extent that the scarcity rents exceed the costs the firms incur from retrofitting to meet the new standards. Voluntary standards, certification and labeling systems do not require reorganization of existing regulatory regimes or compliance by industry. See Livermore, supra note 110, at 383 (arguing in favor of preference-based regulation). While Livermore focuses on preference-directed governmental regulation, in which the government requires or encourages market actors to provide information, his critiques and insights are equally applicable to voluntary standards, certification and labeling systems.

203. Id. (arguing for preference-based governmental regulation). Lobbying in order to obtain rents, a price premium or a greater market share, by, for instance, preventing a beneficial change in the law, is economically wasteful. The opposition to a change in the law is driven by special interest groups with vested interests in the status quo. They obtain a private marginal benefit that exceeds their own costs. However, the social marginal costs to those who would benefit from a change in the law are diffuse. 
increasing demand for their certified products. With voluntary standards, scarcity rents do not arise. ${ }^{204}$ Firms may choose to retrofit to meet the standard or continue with business as usual.

Voluntary standards, certification and labeling systems also avoid the hazards that give rise to regulatory "ossification.” When government agencies have been able to regulate effectively for an initial period, over time these regulations may become rigid and ineffective, or "ossified." Regulatory ossification occurs when government regulation fails to change despite changed circumstances. ${ }^{205}$ Most current federal and state regulations are in the form of command-and-control regimes. ${ }^{206}$ These systems have been heavily criticized as failing to accommodate innovation, prioritize risks, recognize ecosystem interdependencies, coordinate with other related regulation, respond to changed circumstances and show democratic accountability. ${ }^{207}$ Effective regulatory regimes must be evaluated and modified over time to meet regulatory needs and adapt to new circumstances. ${ }^{208}$ A variety of dynamics may prevent this necessary evaluation from occurring; consequently the regulations become ossified. ${ }^{209}$

Ossification may be inevitable for certain forms of governmental regulation, since it results from stable political equilibria. ${ }^{210}$ Ossification occurs, in part, because the institutional rulemaking authorities, the courts, the

204. See Don Fullerton, A Framework to Compare Environmental Policies, 68 S. ECON. J. 224, 232-36 (2001) ("A scarcity rent is created because government has restricted the amount of production and consumers place a higher value on the remaining units of production.”).

205. See Livermore, supra note 110 , at 337.

206. Id. at 319 .

207. Id. at 319 (quoting Richard B. Stewart, A New Generation of Environmental Regulation? 29 CAP. U. L. REV. 21, 22 n.1 (2001)).

208. Livermore, supra note 110 , at 356.

209. For example, regulations for energy efficiency standards, first enacted in 1978, have been largely ineffectual. See Alexandra Klass, State Standards for Nationwide Products Revisited: Federalism, Green Building Codes, and Appliance Efficiency Standards, 34 HARV. ENVTL. L. REV. 335 (2010). This ineffectiveness has resulted in part from the Department of Energy's failure to set the standards and in part from their failure to update them. See id. at 347-53. Despite legislation, public interest groups were forced to bring suit to move the Department of Energy to set the standards required by law. See id. at 347 n.74; Natural Res. Def. Council v. Herrington, 768 F.2d 1355, 1433 (D.C. Cir. 1985). Even when the legislation itself has provided for standards to be reviewed and improved over time according to a set schedule, agencies have still failed to adhere to the legislative mandate. See Klass, supra, at 349-52. Often, even when standards are updated, they provide no spur to innovation or consumer access to improved products because the standards are set below the existing industry standards for products in the marketplace. Id. at 352-53. In many cases, federal preemption bars states or other private parties from setting more stringent standards, limiting the ability of states to innovate. Id. at 355. While the standards for appliance efficiency permit states to seek a preemption waiver, the burden of proof for the state is very high. Id. at 358 ("[T]he waiver for state appliance efficiency standards... is considered impossible to obtain.”). The state must also provide evidence of costs, benefits and reliability - information that is readily available to the manufacturers, but would entail significant expenditures for the states to provide. Id. at 361. While only California has ever sought a preemption waiver, none have been granted. Id.

210. Livermore, supra note 110, at 311, 315, 345-55. 
legislature and the media are subject to public-choice dilemmas. ${ }^{211}$ The checksand-balances system also favors the status quo because the rulemaking process is slow and costly. ${ }^{212}$ The likelihood that new rules will survive the gauntlet of vetoes that may appear at every level is low. ${ }^{213}$ Therefore, agencies are systemically incentivized to reject regulatory change.

Voluntary standards, certification and labeling systems instead spur innovation, drive change and break through the existing regulatory stalemate. $^{214}$ By anticipating current and future public norms in developing standards, these systems perform an entrepreneurial function. ${ }^{215}$ They ease the way for shifts in public values, promote innovation in industry and change in government standards, and avoid many of the social costs associated with rentseeking and agency capture through their public deliberation processes. ${ }^{216}$ Since voluntary standards, certification and labeling systems shift demand to products with fewer social costs, they encourage innovation and incentivize the development of alternative products. ${ }^{217}$ By focusing on consumer demand, the schemes change consumer preferences through the provision of information and the creation and strengthening of norms. ${ }^{218} \mathrm{By}$ "making externalities more visible," the systems enhance efficiency-when consumers are able to see the environmental impacts of their consumption choices, they have the opportunity to choose the good with the lower environmental or other social cost. ${ }^{219}$

\section{B. Institutional Weaknesses}

While voluntary standards, certification, and labeling systems may address many hazards associated with government regulation, they are not a substitute

211. Id. at 337. First, the benefits from legislating are outweighed by the costs. It is easier to block an action of an agency than to promulgate a new rule and to move it forward. $I d$. at 345 . Entrenched interests will lobby and make campaign contributions to prevent regulation from occurring. Id. Because industry interests are concentrated, whereas public interest groups tend to be diffuse, industry is better able to overcome any collective-action problems to mobilize to influence legislation through lobbying efforts. Id. Consequently, special interest groups may “capture” individuals within the legislative process, such as committee members or key legislators. Id.

212. Id. Development of proposed rules may take years, and the Administrative Procedures Act provides for multiple rounds of public notice, review and comment periods. The Office of Management and Budget is charged with the task of overseeing agency rulemaking decisions; the Office requires agencies to perform a cost-benefit analysis on proposed rules and their alternatives. Id. at 337. Private interests may delay or bar the implementation of a new rule by bringing suit under the Administrative Procedures Act, and rules that took years to develop may swiftly be stricken down by the courts for failure to adhere precisely to the requirements of the Act. Id. at 337-38.

213. Risk-averse bureaucrats avoid innovation and maintain the status quo, in part, because they serve so many “masters.” Id. at 350-52. Innovation invites critique by current congressional committees, the White House (functioning through the Office of Management and Budget), particular legislators and the media. Id. at 353. In contrast, inaction is boring and not particularly newsworthy. Id. at 353-54.

214. Id. at 314. Livermore's arguments in favor of preference-directed governmental regulation often apply equally to voluntary standards, certification and labeling systems.

215. Meidinger, supra note 1 , at 531-32.

216. Id. at 532 .

217. Livermore, supra note 110, at 371-73.

218. Id. at 326-27.

219. Id. at 330 (quoting Stewart, supra note 13, at 134). 
for it. Full internalization of negative externalities within an industry would mandate participation by consumers and producers. Only a mandatory regime could assure that there were no free-riders - that all parties pay the full cost of production. With a voluntary regime, to the extent that consumers are more concerned about price than about other social costs that they or others may bear, they will select according to price rather than certification. The demand for goods under voluntary standards, certification and labeling systems appears to vary based on whether the cheapest cost avoider bears the costs or the best briber bears these costs. When the best briber bears the social costs associated with consumption, demand for substitute, "clean" goods is higher. For example, when consumers and their families bear the health and other costs associated with chemical exposures, ${ }^{220}$ the aggregate demand for products and services that help consumers avoid those exposures is higher. ${ }^{221}$

When the harms to the best briber are temporally remote, ${ }^{222}$ or when the cheapest cost avoider bears the social costs of production, ${ }^{223}$ consumer demand is lower. In general, consumers buying this set of labeled goods seek not a benefit for themselves, but a benefit for the parties that harvest or manufacture the goods the consumers are purchasing. They purchase labeled goods out of concerns for fairness, or feelings of solidarity or charity towards the cheapest cost avoider and a desire to reduce their social costs. ${ }^{224}$ These systems have been enhanced and supported through the use of social networks to educate

220. These systems include organic agricultural standards, the "Green Seal” labeling system and certain elements of the LEED standards that verify the chemical content of products. See supra notes 49, 64 and 165 and accompanying text.

221. See, e.g., CATHERINE GREENE ET AL., USDA ECON. RESEARCH SERV., EMERGING ISSUES IN THE U.S. ORGANIC INDUSTRY, ECONOMIC INFORMATION BULLETIN NO. EIB-55 (2009) available at http://www.ers.usda.gov/publications/eib-economic-information-bulletin/eib55.aspx ("Significant price premiums, fast-paced growth in demand, and fluctuating market conditions have characterized the U.S. organic sector since the beginning of the decade. Early in the decade, demand for organic products outpaced supply, and market participants reported that a supply squeeze was limiting growth in the overall sector. For example, 44 percent of organic handlers reported short supplies of needed ingredients or products in 2004, according to an ERS nation-wide survey, and 13 percent were unable to meet market demand for at least one of their organic products that year.”).

222. See supra notes 38-41 and accompanying text for description of "best briber." These systems include the Marine Stewardship Council ecolabeling system, which seeks to avoid fishery collapse and loss of biodiversity and species integral to ecosystems, and to promote the harvesting of fish stocks in a way that permits the species to perpetuate themselves. See supra notes 138-145 and accompanying text. The Forest Stewardship Council's system would also qualify as providing temporally remote benefits, since it seeks to reduce deforestation to avert the larger global losses associated with climate change. See supra notes 87-88, 99, 105 and 109 and accompanying text.

223. These systems include the Fairtrade initiatives, which were developed to provide improved market access and better trade conditions for small scale farmers and other producers, and to help them receive stable and higher prices for their products. DANKERS, supra note 67, at 5.

224. Courville, supra note 57, at 278 ("The fair trade movement, of which FLO [Fairtrade Labeling Organization] is a part, was started by church organizations and international solidarity NGOs, among others. The difference between FLO and the rest of the fair trade movement is that FLO targets mainstream consumers through the use of a label rather than through alternative shops and community networks.”). 
consumers and support a shift to labeled goods. ${ }^{225}$ Following World War II, religious networks began to establish norms relating to fairness in respect of their members' purchase of goods; this practice formed the initial basis for establishing fair-trade certification and labeling systems. ${ }^{226}$ For example, the market for Fairtrade coffee was developed to support farmers in Central and South America following the collapse of the coffee market in 1989. ${ }^{227}$

In addition, the programs may be strengthened by focusing on consumer goals. For example, consumers of Fairtrade coffee are likely motivated to purchase this coffee to support coffee farmers and their workers because the Fairtrade system provides a guaranteed price and a Fairtrade premium. ${ }^{228}$ Voluntary standards, certification and labeling systems that are designed to support the financial wellbeing of small producers would therefore be strengthened by mechanisms that offer the consumer transparency with respect to the price premiums paid. Specifically, consumer demand would likely increase if consumers could verify the extent to which their premium actually reached the producers, after covering the operational costs of the certification and labeling system itself, rather than being absorbed by the distributors or retailers. This could be expressed either as a percentage of the premium or a percentage of the total cost of the good being purchased. The value of the premium being delivered to the producer could also be expressed on a purchasing power parity basis to help clarify to the consumer what that premium will allow the producer to purchase in their own country.

Because the systems are voluntary, participation by suppliers would also likely be low. As a consequence, the price premium necessary to cultivate full supplier participation would likely be high. The premium would also decline as more suppliers shifted to the new regime. As supply of the clean goods increases, the price of clean goods declines, reducing any premium available. In addition, the more suppliers that join the regime, the greater the benefit of

225. In the United Kingdom and Europe in the 1950s, Oxfam began importing and selling handicrafts made by refugees, and in 1964, it developed the first Alternative Trading organization to connect small-scale farmers and producers directly with consumers. DANKERS, supra note 67, at 5.

226. In the 1940s, in the United States, Ten Thousand Villages and SERRV (formerly known as "Sales Exchange for Refugee Rehabilitation and Vocation") developed programs to trade with refugee and poor communities in developing nations. DANKERS, supra note 67, at 5. SERVV began as a group of church-based relief workers that were assisting refugees in post-World War II Germany by selling their handicrafts in the United States. See Our Story, SERRV.ORG, http://www.serrv.org/category/ourstory (last visited Mar. 5, 2013).

227. Max Havelaar Keurmerk was the first fair-trade label, developed in 1988 to market the product of small-scale coffee producers. DANKERS, supra note 67 , at 5 . The label was developed by "Solidaridad," a Dutch NGO, to expand the distribution of fair-trade products and to provide assurance that the labeled goods met certain labor and environmental standards. How Did It Start, MAX HAVELAAR FOUND., http://www.maxhavelaar.nl/faq/how-did-it-start?destination=english\&backtitle= FAQ\%27s (last visited Mar. 5, 2013).

228. In 1997, the Fairtrade Labeling Organization (FLO) was developed to serve as an umbrella organization for seventeen national fair-trade labeling initiatives. DANKERS, supra note 67, at 23. The organization developed labor standards, standards for farmers' associations and cooperatives, trade standards and environmental standards. Id. The trade standards require traders to pay a minimum price set by FLO, plus a fair-trade premium. Id. 
savings to those who choose not to join the regime and continue business as usual. While voluntary standards, certification and labeling systems encourage participation by various means, the systems cannot require participation; the systems are, by definition, voluntary and lack the force of government sanction to mandate participation and compliance. Consequently, they cannot solve the free-rider problem. ${ }^{229}$

Another hazard that voluntary standards, certification and labeling systems face is fraud and unfair competition from organizations that purport to adhere to social and environmental standards, but do not actually take any action to address these concerns, a practice known as "greenwashing." 230 The Federal Trade Commission has in recent years begun to regulate "green" claims, deter fraud and support consumer awareness and choice. ${ }^{231}$ To provide guidance to firms and organizations making claims of environmental sustainability, the Commission has produced a series of Guides for the Use of Environmental Marketing Claims to identify a safe harbor against claims for unfair or deceptive advertising under the Federal Trade Commission Act for firms that make specific environmental claims and provide substantiation for those claims. ${ }^{232}$

In addition, many voluntary standards, certification and labeling systems developed by nonprofit-based or tripartite-run organizations face competition from similar systems developed by industry or industry trade associations. ${ }^{233}$ For example, two industry associations, based in the United States and Europe, have developed in response to the Forest Stewardship Council: Sustainable Forestry Initiative and the Programme for the Endorsement of Forest Certification. ${ }^{234}$ In the late 1990s, the Apparel Industry Partnership

229. When an investment has a personal cost but a common benefit, individuals will tend to underinvest or fail to pay their fair share of the costs necessary to claim the benefits. GRUBER, supra note 19, at 134. In this context, consumers would have a tendency to free ride, paying less than the full cost associated with the manufacture and production of the goods they purchase and leaving it to others to address negative impacts of their consumption. Producers would tend to externalize the environmental and other social costs of their production processes in order to gain a price advantage in bringing their goods to market.

230. See Andrew Hoffman \& Stephanie Bertels, Who Is Part of the Environmental Movement?, in GOOD COP, BAD COP: ENVIRONMENTAL NGOS AND THEIR STRATEGIES TOWARD Business , supra note 70, at 48, 62 ("[G]reenwashing [is] a term that implies presenting misleading information to conceal an organization's abuse of the environment and present a positive public image.”). See also Eric L. Lane, Consumer Protection in the Eco-Mark Era: A Preliminary Survey and Assessment of AntiGreenwashing Activity and Eco-Mark Enforcement, 9 J. MARSHALL REV. InT’L PROP. L. 742 (2010). The term appears to have been developed as a result of accusations that firms were "whitewashing" the environmental harms they were causing by claiming "green” credentials.

231. See 15 U.S.C. § 45 (2012) (authorizing the Federal Trade Commission to investigate unfair trade practices and deceptive advertising affecting commerce, to issue orders prohibiting such actions and to enforce the orders with civil penalties and equitable relief.)

232. The Commission's Guides for the Use of Environmental Marketing Claims specify a safe harbor against claims that firms have engaged in unfair or deceptive trade practices or advertising under the Federal Trade Commission Act. If the environmental claims are sufficiently specific and the firms are able to substantiate those claims, they can avoid liability. 16 C.F.R. §§ 260.1- 260.8 (2012).

233. Abbott \& Snidal, supra note 82, at 76.

234. Id. 
collaborated with the Clinton Administration, the Union of Needletrades, Industrial, and Textile Employees, NGOs such as the Lawyers Committee for Human Rights and International Labor Rights Fund, and apparel manufacturers to develop the Fair Labor Association. ${ }^{235}$ The organization was formed to monitor and certify industry supply chains to address sweatshop labor practices. ${ }^{236}$ The Association certifies apparel-industry supply chains. ${ }^{237}$ In response, the apparel industry developed Worldwide Responsible Apparel Production to compete with the Fair Labor Association; it certifies factories. ${ }^{238}$ While the industry-supported voluntary standards, certification and labeling systems may contain standards that are specific and enforced, they may not be prescriptive, ${ }^{239}$ requiring actual improvement over the status quo. ${ }^{240}$ If they are not prescriptive, they provide little assurance to consumers that environmental or social costs are being internalized. ${ }^{241}$

Non-prescriptive labels create disutility. They free-ride on the recognition of stringent labels, siphoning off "green premiums" to which the stringent labels are entitled. Consequently, the diversion of environmental and socially responsible premiums to less-stringent brands has a negative economic impact on the communities and firms producing goods under the more stringent standards. ${ }^{242}$ Non-prescriptive labels also cause confusion in the marketplace and contribute to label fatigue, desensitizing consumers and dampening demand. ${ }^{243}$

235. Bartley, supra note 68, at 449-50.

236. Id.

237. Errol Meidinger, Beyond Westphalia: Competitive Legalization in Emerging Transnational Regulatory Systems 18 (Buffalo Legal Studies Research Paper No. 2006-019, 2006), available at http://papers.ssrn.com/sol3/papers.cfm? abstract_id=917952.

238. Id.

239. Errol Meidinger, The Administrative Law of Global Private-Public Regulation: The Case of Forestry, 17 EUR. J. INT’L L. 47 (2006).

240. Standards that are not sufficiently prescriptive or fail to include benchmarks or other metrics for measuring improvement reduce label credibility. Courville, supra note 57, at 280, 283.

241. One scholar has suggested that federal trademark law could be modified and expanded to support voluntary standards, certification and labeling systems as global governance institutions and to reduce the consumer confusion that results from label clutter. See generally, Chon, supra note 109. Chon's proposed modifications to the Lanham Act and other trademark and service mark protections include: 1) disclosure of the system's substantive standards as a prerequisite to registration or enforcement of the trademark, service mark, collective mark or certification mark used to identify the certification system; 2) use of the doctrines of "abandonment" and "control" to incentivize quality control; 3) use of the doctrine of trademark misuse to prevent the enforcement of any mark where deceit or fraud are involved; and 4) expansion of standing to permit consumers to bring actions against participating producers that use the label but do not meet the system's standards. Id. at 138-40.

242. Consumers may see the process of promulgating the standards as symbolic, failing to produce improvement in social and environmental conditions. See Courville, supra note 57, at 287-88; King et al., supra note 56, at 1094. Skepticism relating to one label may impact other labels, reducing all of their credibility. Courville, supra note 57, at 290.

243. W. Kip Viscousi, Using Economics to Fuel Responsible Energy Consumption Decisions, 38 ENVT'L. L. REP. 10,842, 10,845 (2008) (describing the dangers of label clutter, including so much information on the label that the consumer cannot process it, and label fatigue, label ineffectiveness resulting from a plethora of labels that stigmatize all choices, leaving the consumer with no clear decision that would improve outcomes). 
There is also a disparate distributional impact between stringent and mediocre labels. Members of the public may choose between a substitute "clean" good, paying a higher price for enhanced utility, and the good with negative production externalities (the "dirty" good), paying a lower price but retaining the savings. To the extent that a consumer purchases a mediocre label, thinking it is a stringent label, the consumer suffers disutility; the consumer is likely to have paid more than he would have paid otherwise and accomplished less with his choice. In addition, to the extent a consumer chooses the "clean" good at times and the "dirty" good at others, the savings from selecting the "dirty" good are retained by the consumer. ${ }^{244}$ But, when consumers purchase goods with non-prescriptive labels as a means to choose a middle path between the "clean" and "dirty" goods, the economic benefit accrues to the firm or organization using the non-prescriptive label rather than to the consumer.

Furthermore, when there are competing labels, consumers must spend time evaluating the standards. ${ }^{245}$ This time investment undermines the function of the label, which is to provide a streamlined assurance about the quality of the good, reducing consumer search and assessment costs. ${ }^{246}$

Finally, all of these systems are expensive; it takes time, effort and substantial financial support to ensure that social costs are avoided or minimized and to certify to consumers that this desirable outcome has in fact occurred. Consumers seeking certified goods generally bear higher prices. The existence of voluntary standards, certification and labeling systems sometimes draws into question whether this ought to be the case-whether the existing allocations of entitlements and distribution of costs and benefits across the population is the appropriate one.

\section{Rule 4 Institutions Reveal Inefficient Allocations}

Industry growth, market share and public support for and use of products labeled through voluntary standards, certification and labeling systems are measures of public preference. ${ }^{247}$ While incomplete, they provide insight as to

244. However, with voluntary standards, the externality is reduced only to the extent that the consumers select clean goods.

245. Darby \& Karni, supra note 55, at 84. The scholars describe government intervention to provide information about firms producing credence goods by rating the firms providing the goods. See $i d$. ("One technique of government information production is to rate the output of firms on the basis of an appropriate sample. This sort of rating would also be produced in the market, but requires consumer monitoring of the rating firm in turn. If the government produces ratings, the consumer must instead monitor the quality of the government ratings.”).

246. A number of private organizations have begun efforts to evaluate these voluntary standards, certification and labeling systems. Recently, the World Resources Institute and Big Room Inc. developed a survey to provide information on the performance and organizational structure of ecolabels. Of the 340 ecolabel programs surveyed, 33 percent completed the survey, 42 percent were not reached, 14 percent began the survey but did not complete it, and 10 percent declined to do the survey at all. The survey results were published online in July 2010. See 2010 Global Ecolabel Monitor, WORLD RES. INST., http://www.wri.org/publication/global-ecolabel-monitor (last visited Mar. 2, 2013).

247. The limited nature of this measure is largely the result of the credence goods problem and the dearth of information about toxic exposures and risk. See supra notes $72-80$ and accompanying text. 
the disutility associated with the current allocation of entitlements. ${ }^{248}$ First, increasing consumer participation in these programs indicates a shift in perceptions of and tolerance for risk. ${ }^{249}$ For example, a number of organic and biodynamic agriculture schools and publications were developed in the United States, England and Germany in response to technological innovations in agriculture adopted following World War I. ${ }^{250}$ After World War II, NGOs developing regional organic and tilth standards began to proliferate throughout the United States as the federal government began to provide institutional support for industrialized agriculture. ${ }^{251}$ These standards were subsequently adopted and codified first as state and then as federal law. ${ }^{252}$ The organic food industry experienced 267 percent growth between 1990 and 2010, with 7.7 percent growth between 2009 and 2010,253 during a national economic recession. Organic foods generated \$28 billion of U.S. food sales in 2011. ${ }^{254}$

248. Consumers adjust to the increased health risks associated with pollution in a number of ways. One way is to reduce risk by reducing exposure. See President's CANCER PANEL, U.S. DeP'T OF Health and Human Servs., Reducing Environmental Cancer Risk, What We Can Do Now xix-xx (2009), available at http://deainfo.nci.nih.gov/advisory/pcp/pcp.htm. For air pollution, this may require moving to rural areas; for water pollution, it may entail installing special water filters. Id. If a consumer is concerned about exposing himself to chemical toxins in food produced with chemical fertilizers and pesticides, he can pay a premium for organically grown produce, meat, and poultry. Id. When the government has allocated risks and costs to the public that members of the public do not want to bear, voluntary standards, certification, and labeling systems allow the public to pay a premium to avoid those risks. Consumers are increasingly turning to these systems to help them reduce these exposures and impacts.

249. Even as exposure information becomes more available for a wide array of chemicals, and science improves testing to monitor the "total body burden" or bioaccumulation for these chemicals, scientists have only just begun to research the pathways by which exposure and bioaccumulation result in cancer, neuropathology and developmental and reproductive harms. Recently, the mainstream medical establishment has joined the call for concern about health risks from environmental exposures. See, e.g., Nicholas Kristoff, New Alarm Bells About Chemicals and Cancer, N.Y. TimES, May 6, 2010, at A33 (citing the President's Cancer Panel Report). The President's Cancer Panel issued a report that examines how cancer risks are impacted by environmental exposure in industrial, occupational, agricultural, medical, military and natural settings as well as exposures that arise from modern lifestyles. See supra note 248 . The report identifies the key barriers to public action and provides recommendations how citizens may overcome the political, regulatory, industrial and cultural barriers to reducing their exposure to cancer-causing substances. See id. at 103-09 (Chapter 3, "Policy Research and Program Recommendations”).

250. See generally FROMARTZ, supra note 7, at 6-27 (describing the development of the organic movement and its most influential figures).

251. Id.

252. The Organic Food Production Act of 1990 was enacted under the Food, Agriculture, Conservation, and Trade Act of 1990 (the 1990 Farm Bill), Pub. L. No. 101-624, Title 21 (7 U.S.C. § 6501-22).

253. See ORGANIC TRADE Ass’n, http://www.ota.com/organic/mt/business.html (last visited Mar. 5, 2013). According to the Organic Trade Association, "U.S. sales of organic food and beverages have grown from \$1 billion in 1990 to \$26.7 billion in 2010. Sales in 2010 represented 7.7 percent growth over 2009 sales. Experiencing the highest growth in sales during 2010 were organic fruits and vegetables, up 11.8 percent over 2009 sales.” Id.

254. With U.S. Food Sales Up 1\%, Organic Value Surges 7.7\% to Over \$28 Bil for 2010, AGRIPULSE (Apr. 21, 2011) http://www.agri-pulse.com/Organic_Industry_Survey_04212011.asp (“Organic food share has grown to $4 \%$ of total food sales.”). 
Similarly, demand for green buildings and green building materials has risen sharply. ${ }^{255}$

Second, the higher prices that the public pays to purchase labeled goods provide a partial measure of the present negative distributional impact of the existing allocation of entitlements. ${ }^{256}$ While the price increases that consumers face in purchasing labeled goods point to an enhanced willingness to pay to avoid risk, those prices do not include the full costs associated with the operation of the labeling programs, which are often privately and publicly subsidized through both tax and spending programs. For example, in 2011, the National Organic Program had a current operating budget of approximately $\$ 10.1$ million. ${ }^{257}$ This was supplemented by $\$ 18$ million in funding for the Organic Agriculture Research and Education Initiative under the Farm Bill, enacted in 2009. ${ }^{258}$ However, this only represents a small fraction of the costs associated with developing the current standards, which grew out of volunteer efforts to develop regional tilth standards. ${ }^{259}$ Many organic certification and

255. See Matt Hickman, Study: Demand for Green Home Building and Remodeling on the Rise, MotHeR NATURE NETWORK (Feb. 13, 2012), http://www.mnn.com/your-home/at-home/blogs/studydemand-for-green-home-building-and-remodeling-on-the-rise (“According to recently published findings from McGraw-Hill Construction's Green Home Builders and Remodelers Survey, the construction of eco-friendly single-family homes represented an impressive 17 percent-or $\$ 17$ billion if you want to put a economic activity-related price tag on it-of the overall American residential construction market in 2011. This is a massive jump from just 2 percent in 2005 and 8 percent in 2008; the number is expected to rise to as high as 38 percent within the next four years and represent a market share of $\$ 87$ billion to $\$ 114$ billion.”); Survey: Tenants Step Up Demand for Green Offices, THE GUARDIAN Feb. 7, 2011, http://www.guardian.co.uk/sustainable-business/tenants-increase-demandgreen-offices; U.S. Demand for Green Building Materials to Exceed $\$ 80$ Billion by 2013, INDUSTRYWEEK (Mar. 10, 2009), http://www.industryweek.com/environment/us-demand-greenbuilding-materials-exceed-80-billion-2013. David Gottfried, Rick Fedrizzi and Mike Italiano established the U.S. Green Building Council in 1993 to transform the building and construction industry and its relationship with the environment. U.S. GREEN BUILDING COUNCIL, ANNUAL REPORT (2008), available at http://communicate.usgbc.org/2008/. In its first fifteen years, the organization grew to include 79 chapters in the US, 18,000 organizational members, 62,000 accredited professionals to perform the certification and consulting services, and 31,000 registered and certified buildings. Id.

256. In the United States, most regulatory action, whether relating to new regulation or existing programs, requires an evaluation of the costs and benefits of regulatory action, deregulation, or inaction. Daniel Cole, Law, Politics, and Cost-Benefit Analysis, 64 AL. L. Rev. 55 (2012). The most controversial and subjective elements of cost-benefit analysis relate to the valuation of human lives and the reduction of mortality, the quality of lives saved or lost, and the discount rate to be applied to the value of future benefits. Id. at 57 . The transaction costs that individuals are currently undertaking to avoid the impacts of the current allocation of entitlements are not plagued with these uncertainties, however. The measurement of these costs does not require estimates of future costs or benefits. They are current day measurements of the additional costs individuals are incurring to avoid risks.

257. U.S. Dep’tT Of Agric., Budget Summary ANd ANNuAl Performance Plan 9 (2011).

258. Id. at 116.

259. In 1924, Austrian philosopher Rudolf Steiner gave a series of lectures, an agriculture course held over ten days in what is now Kobierzyce, Poland, critiquing recent developments in agriculture and laying the groundwork for organic farming. See John Paull, Attending the First Organic Agriculture Course: Rudolf Steiner's Agriculture Course at Koberwitz, 1924, 21 EUR. J. OF Soc. SCI. 64, 65 (2011). One of the first responses to the agriculture course was the development of a Farmers' Association to continue the experimental work. Id. at 65; see also John Paull, From France to the World: The International Federation of Organic Agriculture Movements (IFOAM), 2 J. SOC. RES. \& POL'Y 93 (2010) (describing the history of the organic movement, including the development of the Soil 
labeling organizations are nonprofit, tax-exempt organizations. ${ }^{260}$ Consequently, many of them benefit both from tax exemption on the income they earn in pursuing their organizational mission ${ }^{261}$ and from the subsidy afforded by the deduction for charitable contributions. ${ }^{262}$ Consequently, their annual budgets do not comprehend the complete cost of their operations.

Similarly, the costs associated with the development and operation of the LEED standards offer a measure of the disutility associated with the use of toxics, among other things. ${ }^{263}$ In 2009, the U.S. Green Building Council earned over $\$ 107$ billion in revenues and spent nearly $\$ 54$ billion in program services and $\$ 39$ billion in supporting services. ${ }^{264}$ Again, these numbers are imprecise because the value of substantial volunteer efforts is not quantified. The organization supports its programs through member fees, tax-exempt donations and extensive volunteer efforts. ${ }^{265}$ The LEED standards were developed originally by volunteers, and volunteer panels update the standards every few years and solicit public comments to drive improvements and measure building performance. ${ }^{266}$ Volunteers also conduct and manage the third party certification process for commercial buildings, residential buildings, schools and neighborhoods at both the state and national levels. ${ }^{267}$

Third, in some instances, consumers have pressed for voluntary standards, certification and labeling systems to be incorporated into state and federal law. ${ }^{268}$ Organic standards were first incorporated into U.S. state law in Oregon in $1974 .{ }^{269}$ They have since been incorporated into U.S. federal law in $1990^{270}$

Association in the United Kingdom in 1946, and the institution of IFOAM in 1972, which has grown into an umbrella organization with 804 organizations from 111 counties, generating $\$ 51$ billion in sales); A Brief History of Tilth, SEATTLE TILTH, http://seattletilth.org/about/abriefhistoryoftilth (last visited Mar. 5, 2013) (describing the development of the Tilth Association in 1974 at conference in Washington State entitled "Agriculture for a Small Planet"); History of Oregon Tilth, OREGON TILTH, http://tilth.org/about/history (last visited Mar. 5, 2013) (describing the formation of Regional Tilth by a group of concerned farmers and consumers at a meeting in Washington in 1974 and the development of Oregon Tilth as a subsidiary nonprofit organization under its aegis).

260. See, e.g., OREGON TiLth, http://tilth.org/ (last visited Mar. 5, 2013).

261. See 26 U.S.C. § 501 (2012).

262. See id. § 170 .

263. Note that the LEED standards creates a platform for addressing a number of negative externalities. See supra notes 161-66 and accompanying text.

264. See U.S. GREen Building Council, ANNUAL Report (2010). These numbers do not include state and local chapter revenues and costs.

265. Id.; Charitable Giving to USGBC, U.S. GREEN BUILDING CounCIL, http://www.usgbc.org/ DisplayPage.aspx?CMSPageID=2425\& (last visited Mar. 5, 2013).

266. What LEED Is, U.S. GREEN BUILDING COUNCIL, http://www.usgbc.org/DisplayPage .aspx?CMSPageID=1988 (last visited Mar. 5, 2013).

267. LEED Committees, U.S. GREen BuILDING Council, http://www.usgbc.org/DisplayPage .aspx?CMSPageID=1750 (last visited Mar. 5, 2013).

268. The codification of privately made law in state and national statutes and regulations has precedent in the adoption of lex mercatoria, the commercial law developed privately in the Middle Ages, as a part of English common law and in international commercial law and arbitration systems. Nourse \& Schaffer, supra note 183, at 93.

269. Bob Scowcroft, The Organic Conversation Begins Anew (again), 15 GreEN MONEY J. (2007), available at http://ofrf.org/pressroom/ofrf_news_clips/061200_greenmoneyjournal_scowcroft .pdf. 
and codified with a regulatory apparatus in place since $2000 .^{271}$ The federal government now operates a dual agricultural program, subsidizing industrial agriculture through the Farm Bill ${ }^{272}$ and maintaining the National Organic Program $^{273}$ to help the public protect itself from the impacts of industrialized agriculture. Similarly, while federal, state and local laws contain few restrictions on building materials and substances that may be used in the manufacture of household items and in the construction of the built environment, federal, state and local governments have increasingly mandated the use of LEED standards, in whole or in part, in requisitions for government buildings and interiors and have incorporated the systems into planning, zoning and building codes throughout the United States. ${ }^{274}$

When governments allocate entitlements in one way and then formally adopt regimes that mandate a different allocation of those entitlements or subsidize parties to trade those entitlements privately, questions arise about whether the government's original allocation was appropriate in the first place. Government operation of dual competing regimes cannot be efficient; ${ }^{275}$ it suggests inherent waste and deadweight loss to the economy. These developments-government operation of dual competing systems-may support changing the allocation of entitlements under the existing environmental regime ${ }^{276}$ to grant the public the right to be free of toxins, and to shift to industry the costs associated with determining safe use.

270. See The Organic Food Production Act of 1990, 7 U.S.C. §§ 6501-22 (2012).

271. See National Organic Program Final Rule, 7 C.F.R. pt. 205 (2012).

272. William S. Eubanks II, The Sustainable Farm Bill: A Proposal for Permanent Environmental Change, 39 ENVTL. L. REP. NEWS \& ANALYSIS 10,493 (2009).

273. See The Organic Food Production Act of 1990, 7 U.S.C. §§ 6501-22.

274. See Public Policies Adopting or Referencing LEED, U.S. GREEN BUILDING COUNCIL, http://www.usgbc.org/DisplayPage.aspx?CMSPageID=1852 (last visited Feb. 17, 2012) ("Various LEED initiatives including legislation, executive orders, resolutions, ordinances, policies, and incentives are found in 45 states, including 442 localities (384 cities/towns and 58 counties), 34 state governments (including the Commonwealth of Puerto Rico), 14 federal agencies or departments, and numerous public school jurisdictions and institutions of higher education across the United States.”).

275. When the federal government simultaneously subsidizes contradictory production policies, the result is inefficient. Victor Thuronyi, Tax Expenditures: A Reassessment, 1988 DuKE L.J. 1155, 1161 (1988). Thuronyi critiques as inconsistent and inefficient simultaneous policies to subsidize production through tax policy and to reduce production through agricultural policy. See id. ("While these tax provisions subsidize production and encourage herd expansion, the Department of Agriculture, on the other hand, pays dairy farmers to curtail production and slaughter their herds. Such inconsistency in policy would be much less likely if the Department of Agriculture, rather than the IRS, provided all subsidies to farmers. If the same congressional committee reviewed and the same agency administered all subsidies in a particular substantive area, at least the subsidies would not simultaneously encourage and discourage the same activity. The result would be consistent and more efficient subsidies.”).

276. Laws regulating the use and distribution of chemicals include the Toxic Substances Control Act of 1974, 15 U.S.C. §§ 2601-2692 (2012), the Safe Drinking Water Act of 1974, 42 U.S.C. § $300 f$ (2012), and the Federal Insecticide, Fungicide, and Rodenticide Act of 1996, 7 U.S.C. § 136 (2012), among others. 


\section{CONCLUSION}

Voluntary standards, certification and labeling systems identify and make visible the social, environmental and health impacts of resource extraction, harvesting and manufacturing in global trade. They are Rule 4 institutionsthey facilitate the trade of entitlements by reducing transaction costs. They overcome collective-action problems to aggregate consumer demand, which supports a price sufficient to encourage producers and manufacturers to undertake the costs associated with shifting their production processes. They also aggregate producers to develop a sufficient supply to satisfy the consumer preferences that they are cultivating. The systems reduce transaction costs by connecting producers with consumers and facilitating negotiation and trade between these parties. They also reduce knowledge costs by creating structures to ascertain and verify the quality of goods, track provenance of the goods and label the goods for easy identification by consumers.

Voluntary standards, certification and labeling systems arise primarily in situations marked by "commons" dynamics, including both situations in which natural resources may be overharvested and are likely to suffer the "tragedy of the commons" if no intervention occurs, and situations in which the resource at stake is regulation itself and jurisdictional disjunction, jurisdictional overlap, regulatory fragmentation or uncertainty prevent existing governments from taking action. By creating market structures to permit parties to trade entitlements, these systems enhance efficiency.

Voluntary standards, certification and labeling systems are, by some measures, superior to public regulation. These systems overcome the "institutional ignorance" 277 otherwise imposed on the public as a result of the complexities of global trade and the nature of credence goods, permitting more informed choices by the public. They prove resilient to public choice pathologies associated with the regulatory state, including agency capture, and regulatory ossification. They also cause no sharp transition costs or adverse distributional impacts because they are voluntary. In any given institutional context, voluntary standards, certification and labeling systems deliver desired consumer information and facilitate trade to fulfill consumer preferences.

These systems have a number of structural weaknesses, however. First, they cannot fully internalize negative the externalities because they are voluntary. But they do shift the discourse about what is acceptable, and this may eventually lead to a mandated regulatory response.

Second, because the goods that voluntary standards, certification and labeling systems govern are credence goods, fraud is always a threat. Labels are only as valuable as the monitoring and enforcement systems that maintain the standards and segregate nonconforming goods and their suppliers. To the extent

277. Berry, supra note 56, at 236, 244 ("The global economy institutionalizes a global ignorance, in which producers and consumers cannot know or care about one another, and in which the histories of all products will be lost.”). 
that standards are not maintained, the value of a label is undermined and consumer demand declines. Institutions in which the best briber bears the social costs, such as voluntary standards, certification and labeling systems that permit consumers to purchase goods that reduce their exposures to toxic chemicals, enjoy greater demand. The greatest threat to these institutions is "greenwashing" and fraud in labeling. When multiple labels with varying standards govern the same types of goods, this outcome leads to confusion in the marketplace and "label fatigue." Concerned consumers must then investigate the labels, a task which reduces the value of the labeling systems as time-saving signals that help consumers avoid costs associated with investigating the quality of credence goods. Efforts to provide the public with the means to evaluate these voluntary standards, certification and labeling systems would enhance their value and utility. A number of nonprofit, forprofit and government agencies have risen to this task, with varying degrees of rigor, comprehensiveness and success.

Systems in which the cheapest cost avoider bears the social costs, such as trade, labor and certain environmental labels, or in which the harms to the best briber are temporally remote, have lower demand. These systems may be supported by the use of social networks to educate consumers and support a shift to goods with lower externalized costs.

The existence of voluntary standards, certification and labeling systems may draw into question whether the government's original allocation of entitlements is efficient. For allocations of rights associated with credence goods, price is not an accurate signal for public value of these goods. Situations where governments have adopted competing programs - first setting an allocation and then adopting a certification and labeling system to permit the public to reallocate their entitlements at higher cost-may signal that a reallocation of entitlements is in order. In such cases, the cost-benefit analysis should be revisited, taking into consideration the costs and risks to the public of the existing allocation and the capacity of and the costs to the public to trade that allocation. In this regard, voluntary standards, certification and labeling systems grant insight as to the distributional impacts of an existing allocation of entitlements and provide a partial measure of the transaction costs consumers incur to overcome that allocation.

Finally, voluntary standards, certification and labeling systems draw into question Coase's premise that the primary impediment to managing social costs is a failure to define property rights. These systems arise in the context of government void or government failure-situations in which there is no government that can or will identify, define or assign property rights. Furthermore, voluntary standards, certification and labeling systems do not substitute for the government in assigning them. They do not have that authority. The systems nevertheless facilitate the trade of entitlements. They do so by acknowledging the de facto allocation of property rights and by addressing true impediments to their trade: information and assessment costs, collective-action problems and transaction costs. This finding suggests that 
transaction costs are not only important, but that it is transaction costs-not the lack of properly defined property rights - that are the true impediments to reaching Pareto-efficient allocations of resources, further supporting the use of Calabresi and Melamed's ordering rules in allocating entitlements.

We welcome responses to this Article. If you are interested in submitting a response for our online companion journal, Ecology Law Currents, please contact ecologylawcurrents@boalt.org. Responses to articles may be viewed at our website, http://www.boalt.org/elq. 